WSRC-MS--92-110

DE92 015340

\title{
TRANSURANIC ELEMENT UPTAKE AND CYCLING IN A FOREST ESTABLISHED OVER AN OLD BURIAL GROUND (U)
}

by

C. E. Murphy, Jr. and J. C. Tuckfield

Westinghouse Savannah River Company

Savannah River Site

Aiken, South Carolina 29808

A paper proposed for presentation at the

Seminar on the Dynamics of the Behaviour of Radionuclides in Contaminated Forests

Stockholm, Sweden

May $18-22,1992$

and for publication in the proceedings

This paper was prepared in connection with work done under Contract No. DE-AC09-89SR18035 with the U.S. Department of Energy. By acceptance of this report, the publisher and/or recipient acknowledges the U.S. Government's right to retain a nonexclusive, royalty-free license in and to any copyright covering this report, along with the right to reproduce and to authorize others to reproduce all or part of the copyrighted report. 
PBnoes - thediona

D.B. Moore-Shedrow, Manager

Authorized Derivative Classifier

Transuranic Element Uptake and Cycling in a Forest Established over an Old Burial Ground (U)

C. E. Murphy Jr and R.C. Tuckfleld

Publication Date: February 19, 1992

Approved By: $\quad$ D.B. Moore-Shedrow, Manager

Environmental Sciences Section

Savannah River Laboratory

Westinghouse Savannah River Company

Savannah River Site

Aiken, SC 29808

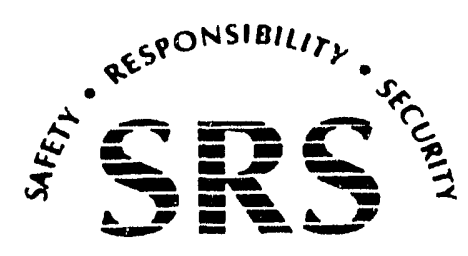

THIS DOCUMENT WAS PREPARED IN CONNECTION WITH WORK UNDER THE U.S. DEPARTMENT OF ENERGY (CONTRACT DE-AC09-89SR18035). 


\title{
TRANSURANIC ELEMENT UPTAKE AND CYCLING IN A FOREST OVER AN OLD BURIAL GROUND
}

\author{
C.E. Murphy Jr. and R.C. Tuckfield \\ Westinghouse Savannah River Company \\ Aiken, SC, USA
}

\section{ABSTRACT}

The consequences of returning the Savannah River Site (SRS) burial ground area to general public access at the time of completion of the SRS :nission is being investigated. This study includes evaluation of the radiological impact to inhabitants of the area under a number of scenarios that include the return of the land to farming or forestry use with or without exhumation of the buried waste.

In the hot, humid climate of the SRS area it is inevitable that the open land will return to forest vegetation if the site is completely abandoned. While this has the desirable effect of limiting erosior, it can be expected that the tree roots will penetrate some distance below ground. In the SRS Low-Level Burial Ground this would provide a vector for movement of radionuclides from waste trenches to the surface. While there have been studies of agricultural species grown on contaminated soil, at SRS and other sites, there are few studies involving forest vegetation. This study was established with the objective of determining the uptake of buried, low-level, transuranic waste from unlined earthen trenches by forest vegetation.

From SRS startup in 1953 through 1974, solid waste contaminated with alpha-emitting transuranic nuclides was buried, unencapsulated, in earthen trenches. Burial records show that this material includes plutonium-238 $\left({ }^{238} \mathrm{Pu}\right)$, plutonium isotopes 239 and $240\left({ }^{239-240} \mathrm{Pu}\right)$, americium-241 $\left({ }^{241} \mathrm{Am}\right)$, and neptunium-237 $\left({ }^{237} \mathrm{~Np}\right)$. 
In 1979, two tree plots were established, one cver a trench in the burial ground and the other in an area without trenches. The alpha waste trench was cored at this time to determine the distribution of alpha contamination under the trench plot. Three species of trees were planted over the trench; loblolly pine (Pinus taeda L.), sweetgum (Liquidambar styraciflua L.), and willow oak (Quercus phellos L.). All are native species. In the two years following establishment of the tree plots, 1979 and 1980, whole trees of each species were collected from each plot and analyzed for ${ }^{239} \mathrm{Pu}$ and ${ }^{238} \mathrm{Pu}$. Beginning in 1986, needle samples were collected from selected pine trees in each of the plots. Because of poor growth and survival, the hardwood trees were not sampled after 1980.

The results of data analysis support the conclusions that: 1) there is more ${ }^{238} \mathrm{Pu}$ uptake by pine tree seedlings than the other species, 2) there is greater transuranic radionuclide uptake in grown pine trees than in seedlings, and 3) there are greater concentrations of transuranic radionuclides in the grown pine trees on the trench plots than in the pine trees on the control plot.

These data indicate that tree roots will extract transuranic isotopes from buried, low-level waste. The amount of radioisotopes moved from the trenches to the surface is small and the level in the trees is low enough that dose from direct exposure will be very small. However, a longer term question is the amount of contamination that will move to the surface through trees and be incorporated in the surface soil after the foliage drops to the soil surface and decays. This process could contaminate surface soil that would later be used to grow food crops.

A model was developed to estimate the potential for this type of transfer from the SRS alpha trenches. The results suggest that even following 100 years of transport, the 
transuranic, alpha dose from consuming food crops grown in the contaminated soil will be much less than from natural isotopes.

\section{INTRODUCTION}

The consequences of the returning the Savannah River Site (SRS) burial ground area to general public access at the time of completion of the SRS mission is being investigated. As part of the program, the uptake of radionuclides by vegetation planted over the burial ground alpha trenches is being studied. This study includes evaluation of the radiological impact to inhabitants of the area under a number of scenarios that include the return of the land to farming or forestry use with or without exhumation of the buried waste.

In the hot, humid climate of the SRS area it is inevitable that the burial ground will return to forest vegetation if the site is completely abandoned. While this would have the desirable effect of limiting erosion, it can be expected that the tree roots will penetrate the low-level buried waste trenches and provide a vector for movement of radionuclides to the surface. While there have been a number of studies of agricultural species grown on contaminated soil, at SRP and other sites [1], there are few studies involving forest vegetarion. This study was established with the objective of determining the uptake of buried, low-level, transuranic waste from unlined earthen trenches by forest vegetation.

From SRS startup to 1966 , solid waste contaminated with alpha-emitting transuranic nuclides was buried, unencapsulated, in earthen trenches. From 1966 to 1974, higher concentrations of alpha waste were encapsulated, but alpha waste with $<0.37 \mathrm{GBq} /$ package continued to be buried unencapsulated. Since 1974 , all alpha waste $>370 \mathrm{nBq} / \mathrm{kg}$ have been stored retrievably. Plant records show that about $148 \mathrm{TBq}$ are associated with 
unencapsulated alpha waste. This includes about $96 \mathrm{TBq}$ of ${ }^{238} \mathrm{Pu}$ and $18.5 \mathrm{TBq}$ of ${ }^{239.240} \mathrm{Pu}$ in the body of this report) buried in about 100,000 cubic meters of trench. Other transuranic nuclides known to be in trench waste include ${ }^{241} \mathrm{Am}$, and ${ }^{237} \mathrm{~Np}$.

The burial trenches were nominally 6.1 meters deep and were capped with 1.25 meters of clean soil. This left the base of the trenches about $6.1 \mathrm{ft}$. above the water table which averages about 12.2 meters in depth in this area [2]. The trench picked for this study was filled in the early period of plant operation, around 1953. The results of an intensive study of this trench was reported by Johnson and Wilhite [3].

Two tree plots were established, one over a trench and the other in an area without trenches. Each plot is 10 meters wide by 35 meters long. The upper 15 centimeters of soil was removed from both sites to minimize contamination due to atmospheric fallout. The soil (n the plots was tested and then limed and fertilized according to local agricultural practices. Then the upper fifteen centimeters of soil was mixed with a harrow. Prior to establishment 0 the sites, the area was mulched with straw to retain moisture, reduce dust, and disconrage inceds.

Three species of trees were planted: loblolly pine (Pinus taeda L.), sweetgum (L iquidambar styraciflua L.), and willow oak (Quercus phellos L.). All are native species. Th s pine is one of the most vigorous pioneer tree species growing in this area. The willow oak and sweetgum are usually more numerous in wetter sites than found in the burial ground but twth could be occasional species even in this type of site. Each plot was divided intc four subplots. Two of the subplots were planted with pine trees, and one of the remaining plots vas planted in oak and the other plot was planted in sweetgum. The trees were planted in three rows, six feet apart. A total of 18 sweetgum, 15 oak, and 36 pines were planted on 
each plot. The center row of the planting was placed along the centerline of the trench. The pine seedlings grew much more vigorously and had a higher survival than the other species. For this reason, sampling of the two hardwood species was discontinued after 1980.

In the two years following establishment of the tree plots, 1979 and 1980, whole trees of each species were collected from each plot for ${ }^{239} \mathrm{Pu}$ and ${ }^{238} \mathrm{Pu}$ analysis. In some cases, the trees were divided into leaf, branch, and stem. In other cases, the whole tree was analyzed. The trees were analyzed by the SRS Environmental Measurements Group. In 1979, soil samples were taken adjacent to each tree sampled. In addition, soil data was available from cores taken in 1979 to characterize the transuranic content of the trench. The vegetation samples were ashed. Plutonium concentration in the vegetation ash and dry soil samples were counted by alpha spectrometry.

The results of sampling of the alpha waste trenches has been presented by Johnson and Wilhite [3]. Some of their results will be included in this report in order to characterize the trench where this study was done. The sampling was done with $5 \mathrm{~cm}$ diameter split-tube and $7.5 \mathrm{~cm}$ diameter Shelby samplers. The Shelby samplers proved to be the most reliable in terms of returning a soil core and account for most of the data. The cores were sampled in 0.6 meter intervals from the surface to 6.75 meters. In their report, the cores were tabulated by 0.6 meter depth intervals in terms of average number of strikes of buried waste materials, the percent of tubes retaining whole soil cores, and the activity of soil. Cores which struck buried material rarely retained a full soil core. Nineteen cores containing 159 segments from 31 linear meters of trench length were taken in the vicinity of the location later used for the vegetation uptake study. 
Beginning in 1986, needle samples have been collected from selected pine trees in each of the plots. Because of poor growth and survival, the hardwood trees were not sampled. In 1986, thirty-one trees remained on the plot over the alpha trench and 26 trees remained on the control plot. During the three years of the study, there has been an increase in the mortality of the trees in the control plot. This appears to have been caused by an increase in the use of herbicides on the steam-line right-of-way adjacent to the plot. In 1988, only 20 trees remained. The alpha trench trees are further away from the right-of-way and do not appear to have been harmed.

Needles were sampled from five trees in each plot during September of 1986 and August of 1987, and 1988. Approximately 500 grams, fresh weight, of needles were removed from each tree. The needles were taken from the base of the branches and represented needles which started growth two springs before sampling (loblolly pine has two years of needles on a branch through the summer of each year dropping to one age class of needles during the fall and winter).

The needles were stored frozen until shipment for analysis by an offsite vendor. The first two years of analysis were done by TMA-Norcal of Richmond, Cal. The 1988 samples were done by TMA-Eberline of Albuquerque, NM. The samples were analyzed for gamma emitting nuclides with a GeLi detector and ${ }^{239} \mathrm{Pu},{ }^{238} \mathrm{Pu}$, and ${ }^{241} \mathrm{Am}$ by alpha spectrometry. in $1987,{ }^{237} \mathrm{~Np}$ was added to the list of radionuclides.

The radionuclide analyses are from three different sources, using slightly different analysis procedures, and reported in different units. The Pu analyses done by the SRS Environmental Measurements Group were reported as $\mathrm{pCi} / \mathrm{gm}$ of ashed tissue. The analyses done by TMA-Norcal were reported in $\mathrm{pCi} / \mathrm{gm}$ dry weight. The analyses done by 
TMA-Eberline were reported in $\mathrm{pCi} / \mathrm{gm}$ wet weight. Conversion from ash weight to a dry weight basis was done under the assumption that the fraction of ash to dry weight was 0.03 [4]. Conversion from wet weight to a dry weight basis was done on the assumption of a water content (wet weight less dry weight divided by dry weight times 100) of $150 \%$ [4]. A comparison of the ${ }^{40} \mathrm{~K}$ activity after conversion from wet weight basis to dry weight basis confirmed the value of water content used.

\section{RESULTS}

Figure 1 illustrates some of the results of coring the waste trenches. The activity in the soil does not include all of the activity available to tree roots. Some of the buried waste had higher activity than the soil around it. The highest activity encountered in the waste was around 100,000 counts/minute as measured with a portable alpha counter. While these measurements were not converted to an activity to weight basis, this waste is the source of the highest soil activity of approximately $15 \mathrm{~Bq} / \mathrm{gm}$ and is almost certainly higher in specific activity than the soil around the waste.

The soil activity shows a general trend of increase from the surface to about $3 \mathrm{~m}$. after which there is an abrupt increase in activity which then remains relatively constant to near the bottom of the trench, at $6.1 \mathrm{~m}$. The activity immediately beneath the trench is only slightly higher than the activity above the trench indicating that vertical migration through the soil below the trench has taken place at a slow rate. The number of strikes of waste objects is in general agreement with the level of activity measured. Many of the strikes were either paper or wood. In most cases, neither of these types of material had degraded very much since they were buried at least twenty-five years earlier. 
Preliminary analysis of the data was done by plotting averages of the individual radionuclide activities for control and trench plots (Figure 2). This plot indicates that there is a an apparent increase in the activity of the needles for the four radionuclides known to be in the trench waste. The difference between the trench and control plot for each year of the study for each radionuclide is illustrated in Figure 3. The difference in the plutonium isotopes between the control and trench plots was very small when the trees were seedlings in 1979 and 1980. The differences between control and trench plots are larger in the period from 1986 to 1988 . There appears to be a small increase in concentration with time for some of the radionuclides during this latter period.

The plots suggest that there were some consistent differences in the average activity of some of the radionuclides. However, even though the samples with the highest activities of the radionuclides measured were from the trench plot, some samples from the trench plot were lower in activity than some of the samples from the control plot. For this reason, it was decided to statistically analyze the data to provide a systematic method of determining the probability that the differences observed between trench and control plots were caused by the presence of the trench materials and not by random variability in the radionuclide content in the natural environment.

The statistical tests were designed to answer three questions 1) was there an effect of tree species, year of collection, or plot (control or trench) on the activity of any of the radionuclides measured in the seedling trees, 2) was there any difference between the activity of any of the radionuclides measured in the pine trees when they were seedlings and after they had grown, and 3) was there an effect of year of sampling or plot on "ne activity of any of the measured radionuclides in the grown pine trees. 
Environmental contaminants such as radionuclides typically show skewed data distributions with relatively many small concentration values and relatively few large concentration values. Asymmetric distributions often preclude the assumption that the underlying population of concentration values is normally distributed.

In such instances, the normal probability model is often replaced by the log-normal probability model. This means that the logarithms of the contaminant concentrations are assumed to be normally distributed [6]. The small sample sizes in the present study were not sufficient to test the normal or lognormal assumptions. Instead, both the natural log-transformed and untransformed (original scale) data were used for statistical analysis. If there was little difference in the results the untransformed results are reported. Otherwise, the log-transformed results are reported.

When log-transformed measurements were used, average concentrations for the corresponding statistical analyses are reported as geometric means. The geometric mean is the mean of the logarithms back-transformed (i.e. exponentiated) to the original scale. An additional consequence of using log-transformed data has to do with the statistical hypotheses being tested. On the original, untransformed scale, we are interested in a test of the hypothesis that there is no difference in the arithmetic mean radionuclide concentrations between plots or years. On the log scale, this is equivalent to a test that the ratio of the respective geometric means is equal to one.

All data, including the data collected when the trees were seedlings, were analyzed by an analysis of variance procedure (ANOVA). For the seedling ANOVA, the main effects include treated (trench) versus control plots, the seedling species, and the year of data collection. Then the analysis of variance procedure was used to determine the effect of tree 
age (seedling versus grown) on radionuclide activity levels for the two plutonium isotopes measured during both periods.

A Repeated Measures ANOVA [7] was chosen for the statistical analysis of the radionuclide concentrations in the pine needles of grown pine trees. The effects tested included treated versus control plots, growth year, and the interaction of plot and year. This method was preferred because radionuclide concentration measurements were repeatedly made on the same experimental units (i.e. trees) at successive time periods, in contrast to the seedling measurements in which it was necessary to sample the whole tree.

All analyses were performed using the SAS statistical computing software [8]. PROC GLM, with the REPEATED statement for the 1986 through 1988 period, producec appropriate tests of each main effect and interaction and resulted in a significance probability or $\mathrm{p}$-value. The p-value is the probability of a false positive conclusion, that is, of concluding that there is a significant effect due to plot or year when, in fact, there is not.

\section{Seedling Analysis}

The analysis of the seedling data showed no significant effect of year of data collection or treatment for either ${ }^{239} \mathrm{Pu}$ or ${ }^{238} \mathrm{Pu}$. However, there is a significant effect of species for ${ }^{238} \mathrm{Pu}(\mathrm{p}<.001)$, but not for ${ }^{239} \mathrm{Pu}(\mathrm{p}<.64)$. The ${ }^{238} \mathrm{Pu}$ results are illustrated in Figure 4, which show the difference in mean activity for the samples between years for each species by treatment. It is clear that the effect of species noted above is for pine trees alone, and is greater in one year than the other. While the activity levels are low compared to later samples taken on grown pine trees, it is possible that the faster growing pines have penetrated the waste during the second year. 
An analysis of variance was performed on the original and log-transformed plutonium isotope data to determine the effect of seedling versus grown pine trees on the activity in the needles. The ANOVA results (untransformed) confirm that the differences between seedlings and grown trees, shown in Figure 2, are significant $(\mathrm{p}<.0001)$. This confirms that radionuclide uptake was higher in the grown trees than in the seedlings. The expected effect of teatment (trench versus non-trench) is also significant ( $p<.0006)$. This is onsistent with the effect of the minimum root penetration into the trenches by the pine seedlings.

\section{Grown Pine Trees}

For the grown pine trees, the results of the statistical analyses on the original data were largely uninformative and generally showed no significant differences in radionuclide

concentrations (except for ${ }^{238} \mathrm{Pu}$ ) between plots or years. However, the same analyses for the log-transformed data did show significant patterns of radionuclide uptake. This was taken as evidence that the lognormal probability model was more appropriate than the normal probability model. Therefore, only the log-transformed analysis results are reported here.

Table 1 contains the geometric mean concentrations for each plot type (averaged across years), for year (averaged across plot type) and for each combination of plot and year. All radionuclides known to have been put into the trench and the natural radionuclide ${ }^{40} \mathrm{~K}$ are represented in this table. For the radionuclides placed in the trench, the geometric mean concentrations are an order of magnitude larger in the treated plots than in the control plots .

Table 2 is a summary of the statistical test results from the repeated measures ANOVA. There was moderate or strong ( $p<.05$ or $p<.01$, respectively) evidence to conclude 
that radionuclide concentration was higher in the treated plot pine trees than in control plot pine trees. The exception is the naturally occurring ${ }^{40} \mathrm{~K}$ for which the ratio of the geometric mean concentrations in the treated and control plots does not differ significantly from one.

Tiable 2 also shows that there is a strong effect of the year of collection in ${ }^{239} \mathrm{Pu}$. The effect of collection year also shows up in a strong $(p<.01)$ interaction effect for ${ }^{239} \mathrm{Pu}$. This means that the ratio of geometric mean concentrations for the treated and control plots varied significantly from one year to anothes Th s effect of year is nonsignificant for the other radionuclides.

\section{DISCUSSION}

The measurements indicate that tree routs will extract transuranic isotopes from buried, low-level waste. The greater uptake of radionuclides by pine seedlings may be a result ol: faster growth and more root penetration into the soil. The greater root penetration into the trench by grown pines is the likely source of the difference in uptake between seedlin|gs and grown pines. The lack of a statistically significant time trend in uptake of most of the radionuclides by the older pines may be an indication that their roots have occupied the soil in the trench and are not expanding further. Few studies are available but data summarized by Koch [4] suggest that pines can occupy most of the available soil volume in less than ten years.

The amount of radioisotopes moved from the trenches to the surface is small and the level in the trees is low enough that dose from exposure will be small. However, a longer term question is the amount of radionuclides that will move to the surface by trees and 
incorporated in the surface soil after the foliage drops to the soil surface and decays. This could contaminate the surface soil that would later be planted to food crops.

A calculation can be made of the potential for transfer through vegetative uptake from the SRS alpha trenches. Table 3 summarizes the transuranic isotope transport calculated using the geometric mean activity found in the foliage during the 1986-88 period and a needle production of $392 \mathrm{gm} / \mathrm{m}^{2}$ [4]. This transpcrt is used to calculate the surface soil activity under the assumptions that all of the radioisotopes accumulated over a 100 year period are held by the soil and the isotopes are evenly distributed in the upper foot of soil by plowing.

Radionuclide specific soil-vegetation concentration factors were used to calculate the radirnuclide activity in vegetable crops from the soil radionuclide concentraitions $[9,10,11]$. In all cases, the activity of the transuranic isotopes in the edible portion of the plants is quite low (Table 4). The activity in the leaf tissue is much higher than in the seed and may, in some cases, be of some concern. However, it should be noted that in all cases the activity is much lower than the natural occurring activity of ${ }^{40} \mathrm{~K}$ in the pine foliage.

The data synthesized by Watters et al. [1] suggests that the availability of transuranic isotopes for plant uptake is related to their mobility in the soil. If this is true, isotopes which are not readily available, such as ${ }^{238} \mathrm{Pu}$ and ${ }^{239} \mathrm{Pu}$, will accumulate in the surface soil over long periods of time and the activity in the surface soil can be expected to increase linearly with time. In this case, the activity of the soil and the plants grown in the soil will be four times higher at 400 years than it was at 100 years. More available isotopes, such as ${ }^{237} \mathrm{~Np}$ and ${ }^{241} \mathrm{Am}$ should also be more mobile in the soil system. In this case, the addition by 
vegetative uptake may be balanced by leaching at some time in the future and a steady state soil activity established.

\section{CONCLUSIONS}

The analysis of the data supports the conclusions that: 1) there are small but statistically significant species differences in ${ }^{238} \mathrm{Pu}$ uptake by tree seedlings;2) there is significantly greater transuranic radionuclide uptake in grown pine trees than in seedlings; 3) the greater concentrations of transuranic radionuclides in the trench plot trees than the control trees are the result of uptake of the radionuclide by the grown pine trees and 4) there is no statistically significant time trend in uptake of transuranic nuclides in the grown trees with the possible exception of ${ }^{239}, 240 \mathrm{Pu}$.

The calculated amount of radionuclides accumulated over longer periods is small in comparison with natural radioactivity in the same soil. However, it would be prudent to continue this experiment to determine whether there is a time trend in uptake by the vegetation. 


\section{REFERENCES}

1. R.L. Watters, D.N. Edgington, T.E. Hakonson, W.C. Hanson, M.H. Smith, F.W.

Whicker, and R.E. Wildung. "Synthesis ofresearch literature". Transuranic Elements in the Environment. ed. W.C. Hanson. DOE/TIC-22800, NTIS, Springfield, VA, pp. 1-44. (1980).

2. J.H. Horton and J.C. Corey. Storing Solid Radioactive Wastes at the Savannah River Plant. DP-1366 E.I. du Pont de Nemours and Company, Inc., Savannah River Laboratory, Aiken, SC 29808 (1976).

3. D.R. Johnson and E.L. Wilhite. Migration of transuranic nuclides in earthen burial trenches at the Savannah River Plant. Sympesium on Migration of Transuranic Nuclides in the Environment, ANS National Meeting, San Francisco, California, November 13-15,1979.

4. P. Koch. Utilization of the Southern Pines, Volume I. USDA, Forest Service, Superintendent of Documents, U.S. Government Printing Office, Washington, D.C. 734 p. (1972).

5. P.J. Kamer and T.T. Kozlowski. Physiology of Trees. p. 229, McGraw-Hill Book Company, New York (1960).

6. R.D.G. Steele and J.H. Torrie. Principles and Procedures of Statistics. McGraw-Hill Book Company, Inc. New York, 481 p. (1960).

7. B. J. Winer. Statistical Principles in Experimental Design. Second Edition. New York, NY. McGraw Hill (1971).

8. SAS. SAS/STAT User's Guide. Release 6.03 Edition. SAS Institute, Inc., Cary, NC, 1028 p. (1988).

9. R.G. Schreckhise and J.F. Cline. "Comparative uptake and distribution of plutonium, americium, curium, and neptunium in four plant species". Transuranic Elements in the Environment. ed. W.C. Hanson. DOE/TIC-22800, NTIS, Springfield, VA, pp. 361-370 (1980).

10. D.A. Cataldo, T.R. Garland, and R.E. Wildung. " Neptunium behavior in plants: absorption, distribution, and fate". Environmental Research on Actinide Elements. eds. J.E. Pinder III, J.J. Alberts, K.W. McLeod, and R.G. Schreckhise, DE86008713,NTIS, Springfield, VA, pp. 97-108 (1987).

11. E.M. Romney, A. Wallace, R.K. Schulz, Jean Kinnear, and R.A. Wood. "Plant Uptake of ${ }^{237} \mathrm{~Np}$, ${ }^{239.240} \mathrm{Pu},{ }^{241} \mathrm{Am}$, and ${ }^{244} \mathrm{Cm}$ from Soils Representing Major Food Production Areas of the United States". Soil Science 132, p40 (1981). 
Table 1. Geometric Mean Concentration (Bq/kg-dry) of Radionuclides from Trench and Control Plots during the Three Year Period (1986-1988).

Each Year (Averaged across Plot Type)

$\begin{array}{llllll}\text { Year } & { }^{241} \mathbf{A m} & { }^{237} \mathbf{N} \mathbf{p} & { }^{238} \mathbf{P u} & { }^{239} \mathrm{Pu} & { }^{40} \mathrm{~K} \\ 1986 & 0.029 & & 0.223 & 0.086 & 178 . \\ 1987 & 0.027 & 0.051 & 0.366 & 0.085 & 155 . \\ 1988 & 0.006 & 0.011 & 0.145 & 0.003 & 190 .\end{array}$

Each Plot Type (Averaged across Years)

$\begin{array}{llllll}\text { Year } & { }^{241} \mathrm{Am} & { }^{237} \mathbf{N} \mathbf{p} & { }^{238} \mathbf{P u} & { }^{239} \mathrm{Pu}_{\mathbf{u}} & { }^{40} \mathbf{K} \\ \text { Control } & 0.003 & 0.001 & 0.061 & 0.009 & 190 . \\ \text { Trench } & 0.877 & 0.429 & 0.755 & 0.078 & 161 .\end{array}$

Each Combination of Year and Plot Type

$\begin{array}{lllllll}\text { Year } & \text { Plot } & { }^{241} \mathbf{A m} & { }^{237} \mathbf{N} \mathbf{n} & { }^{238} \mathbf{P u} & { }^{239} \mathbf{P u} & { }^{40} \mathbf{K} \\ 1986 & \mathrm{C} & 0.010 & & 0.080 & 0.060 & 200 \\ 1986 & \mathrm{~T} & 0.080 & & 0.622 & 0.114 & 158 \\ 1987 & \mathrm{C} & 0.005 & 0.002 & 0.089 & 0.043 & 158 \\ 1987 & \mathrm{~T} & 0.100 & 0.686 & 1.132 & 0.147 & 152 \\ 1988 & \mathrm{C} & 0.000 & 0.000 & 0.031 & 0.000 & 209 \\ 1988 & \mathrm{~T} & 0.840 & 0.267 & 0.611 & 0.029 & 174\end{array}$


Table 2. Summary of Treatment (Plot and Year) Effect Significance from a Repeated Measures ANOVA of the Log-transformed Radionuclide Concentrations.

Effect Significance

\begin{tabular}{|c|c|c|c|}
\hline Badionuclide & Plot" & Year $^{\mathrm{b}}$ & Interaction ${ }^{c}$ \\
\hline $241 \mathrm{Am}$ & Strong $(.01)^{d}$ & Weak (.06) & Weak(.06) \\
\hline 237Np & Strong $(.007)$ & Weak (.08) & -...- (.68) \\
\hline $238 \mathrm{Pu}$ & Strong $(.001)$ & $\ldots-(.33)$ & $\ldots(.67)$ \\
\hline $239 \mathrm{Pu}$ & Moderate $(.02)$ & Strong $(<.001)$ & Strong $(.009)$ \\
\hline 40K & $\ldots-.-(.31)$ & -...- $(.52)$ & ----- $(.90)$ \\
\hline
\end{tabular}

a. The effect due to the presence of radionuclides in the waste trench on the radionuclide concentrations in pine tree needles.

b. The effect of continued year-to-year exposure to radionuclides.

c. Interaction of effect measures whether the plot effect is constant from year-to-year.

d. Significance probability ( $p$-value) in parentheses. 
Table 3. Average Transuranic Isotope Activity, Estimated Isotope Transport, and 100 Year Soil Accumulation Activity over Burial Trench.

$\begin{array}{lllll} & { }^{241} \mathrm{Am} & { }^{237} \mathbf{N} \mathbf{p} & { }^{238} \mathbf{P u} & { }^{239} \mathbf{P u} \\ \text { Trench Plot }(\mathrm{Bq} / \mathrm{kg}) & 0.088 & 0.476 & 0.788 & 0.09 \\ \text { Control Plot }(\mathrm{Bq} / \mathrm{kg}) & 0.005 & 0.001 & 0.068 & 0.03 \\ \text { Transport }(\mathrm{Bq} / \mathrm{hectares} / \mathrm{yr})^{\mathbf{2}} & 324 & 1864 & 2825 & 244 \\ \text { Soil Conconcentration }\left(\mathrm{Bq} / \mathrm{m}^{3}\right)^{\mathrm{b}} & 11 . & 61 . & 93 . & 8.0\end{array}$

a. Transport to surface from trench, assuming foliage production of $392 \mathrm{gm} / \mathrm{m}^{2} / \mathrm{yr}$.

b. Accumulated over 100 years. 
Table 4. Projected Transuranic Isotope Activity in Food Grown in Soil after 100 Years of Vegetation Transport from the Burial Trench to the Soil Surface (Bq/kg-dry). Uptake Coefficients from References [9]-[11].

$\begin{array}{lllll} & { }^{241} \mathbf{A m} & { }^{237} \mathbf{N} \mathbf{n} & { }^{23} \mathbf{P u} & { }^{239} \mathbf{P u} \\ \text { Barley-Grain } & 4.32 \mathrm{E}-05 & 2.35 \mathrm{E}-01 & 2.26 \mathrm{E}-04 & 8.73 \mathrm{E}-06 \\ \text { Barley-Straw } & 4.19 \mathrm{E}-03 & 2.35 \mathrm{E}+00 & 6.36 \mathrm{E}-03 & 4.47 \mathrm{E}-04 \\ \text { Pea-Seed } & & 1.71 \mathrm{E}-04 & 9.55 \mathrm{E}-05 & 1.67 \mathrm{E}-05 \\ \text { Pea-Leaf } & & 5.97 \mathrm{E}-02 & 1.61 \mathrm{E}-01 & 1.30 \mathrm{E}-01 \\ \text { Bean-Seed } & & 9.35 \mathrm{E}-01 & & \\ \text { Bean-Leaf } & & 1.27 \mathrm{E}+01 & \\ \text { Soybean-Seed } & 6.06 \mathrm{E}-05 & 1.93 \mathrm{E}-02 & & 7.02 \mathrm{E}-07 \\ \text { Soybean-Leaf } & 9.08 \mathrm{E}-03 & 7.46 \mathrm{E}-01 & & 2.75 \mathrm{E}-04 \\ \text { Pea-Seed } & 1.88 \mathrm{E}-05 & 2.32 \mathrm{E}-02 & & 9.46 \mathrm{E}-07 \\ \text { Pea-Leaf } & 1.70 \mathrm{E}-02 & 1.60 \mathrm{E}+00 & 6.47 \mathrm{E}-04 \\ \text { Wheat-Grain } & 3.40 \mathrm{E}-06 & 2.10 \mathrm{E}-03 & 9.30 \mathrm{E}-08 \\ \text { Wheat-Straw } & 1.79 \mathrm{E}-04 & 7.95 \mathrm{E}-02 & 1.92 \mathrm{E}-05 \\ \text { Tomato-Fruit } & 1.41 \mathrm{E}-04 & 2.92 \mathrm{E}-02 & 5.19 \mathrm{E}-06 \\ \text { Tomato-Leaf } & 5.37 \mathrm{E}-04 & 6.11 \mathrm{E}-02 & 3.29 \mathrm{E}-05\end{array}$




\section{Figure Titles}

1. The Number of Hits of Activity and the Average Soil Activity Encountered by Soil Coring of the Burial Trench.

2. Figure 2. The Average Activity in Tree Leaves on the Control and Trench Plots for All of the Measured Radionuclides.

3. The Average Difference between Trench and Control Plot Radionuclide Activity for Each Transuranic Nuclide Measured for Each Year Measured.

4. The Average 238Pu Activity Difference between Tree Leaves collected in 1979 and 1980 in Trench and Control Plots for each Tree Species. 


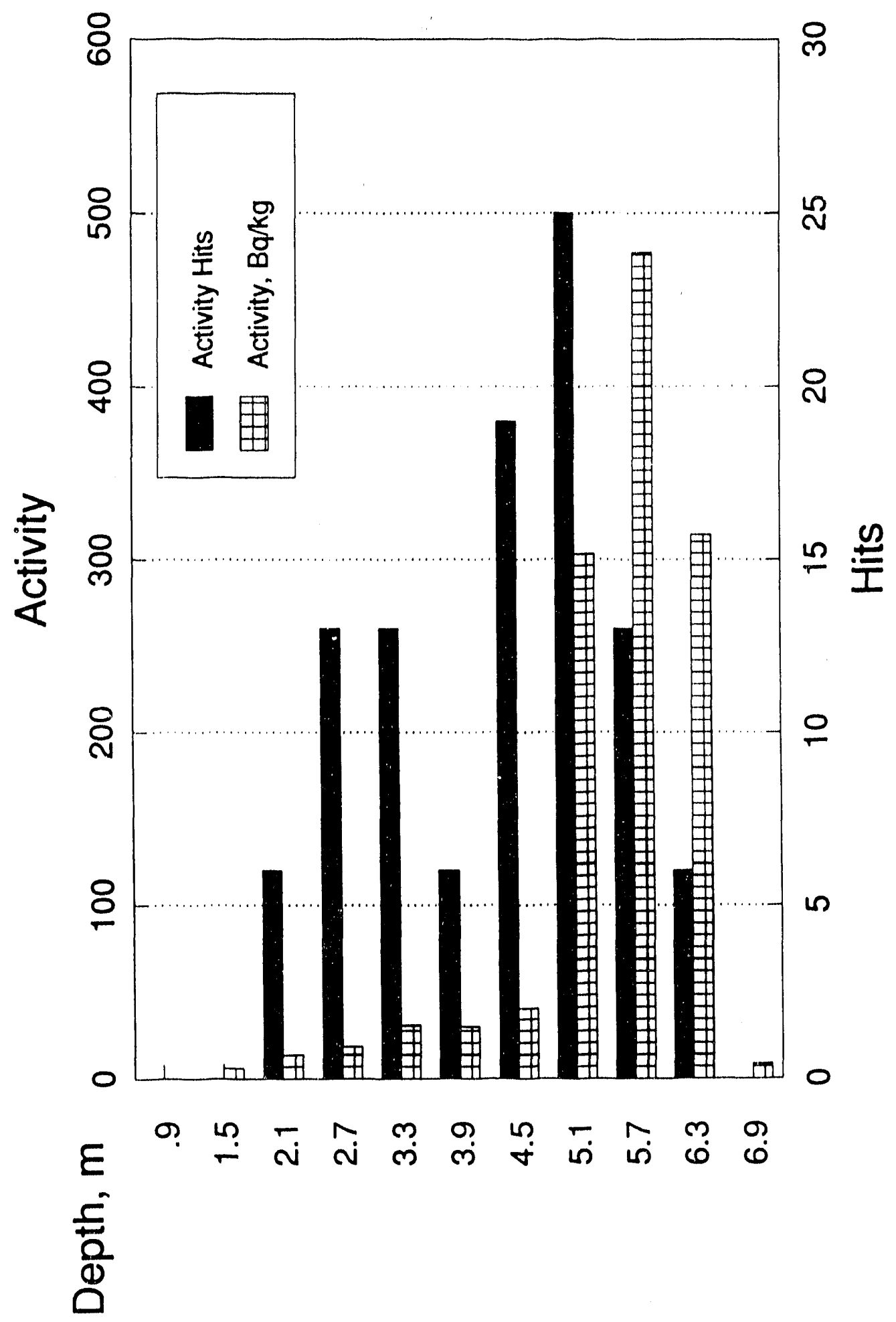




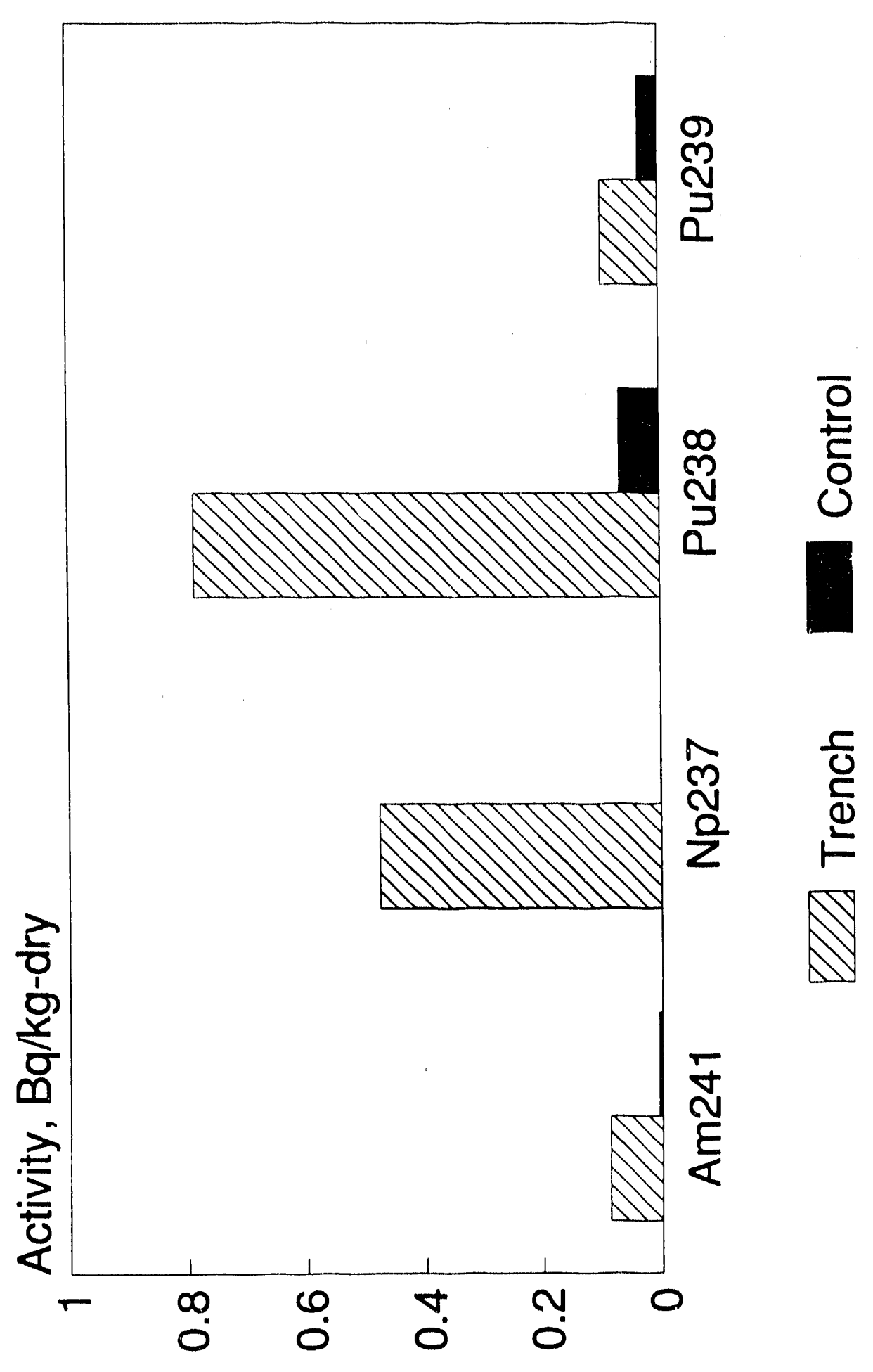




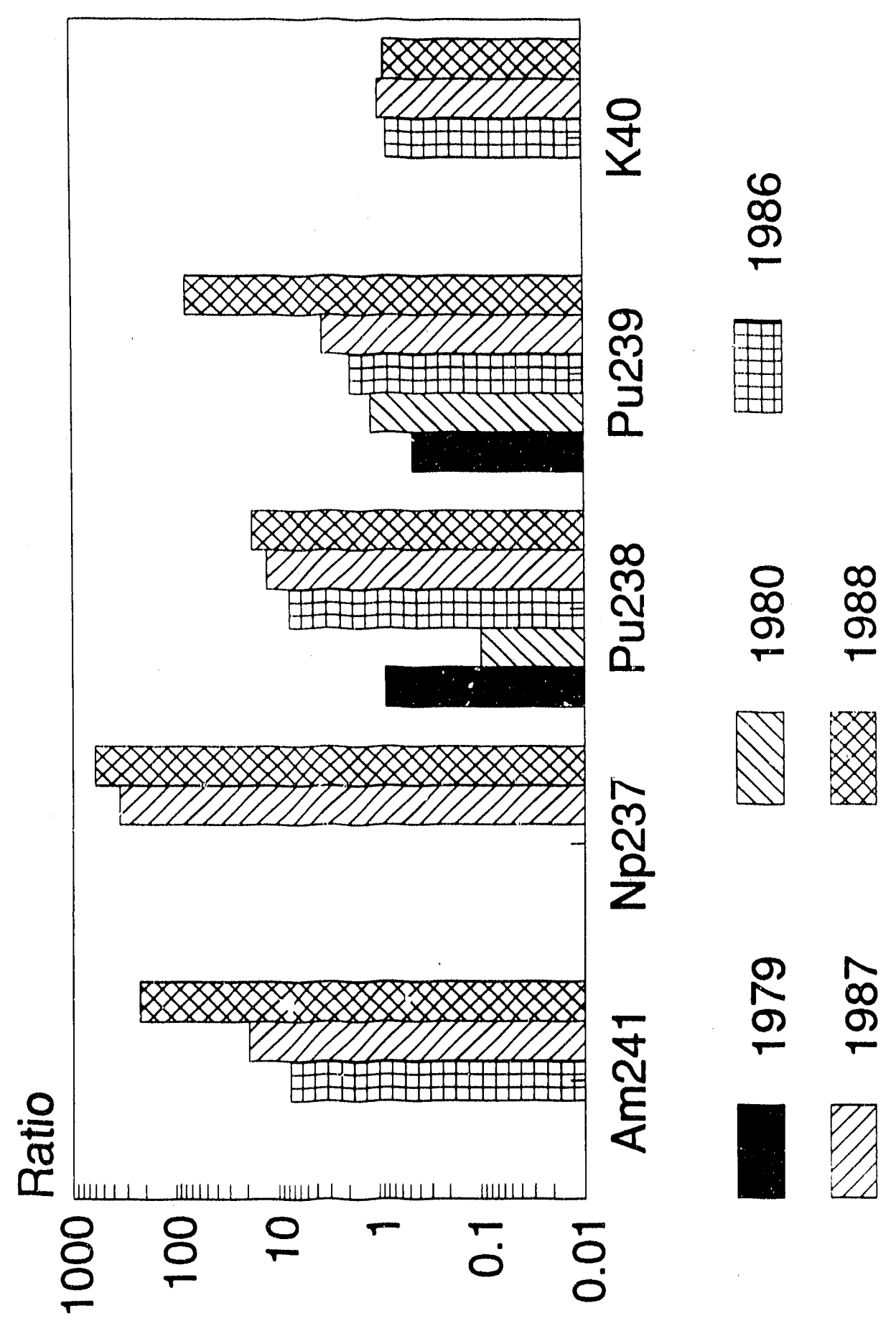




\section{$3 \cdot$ Pu238 Difference, Bq $/ \mathrm{kg}$}

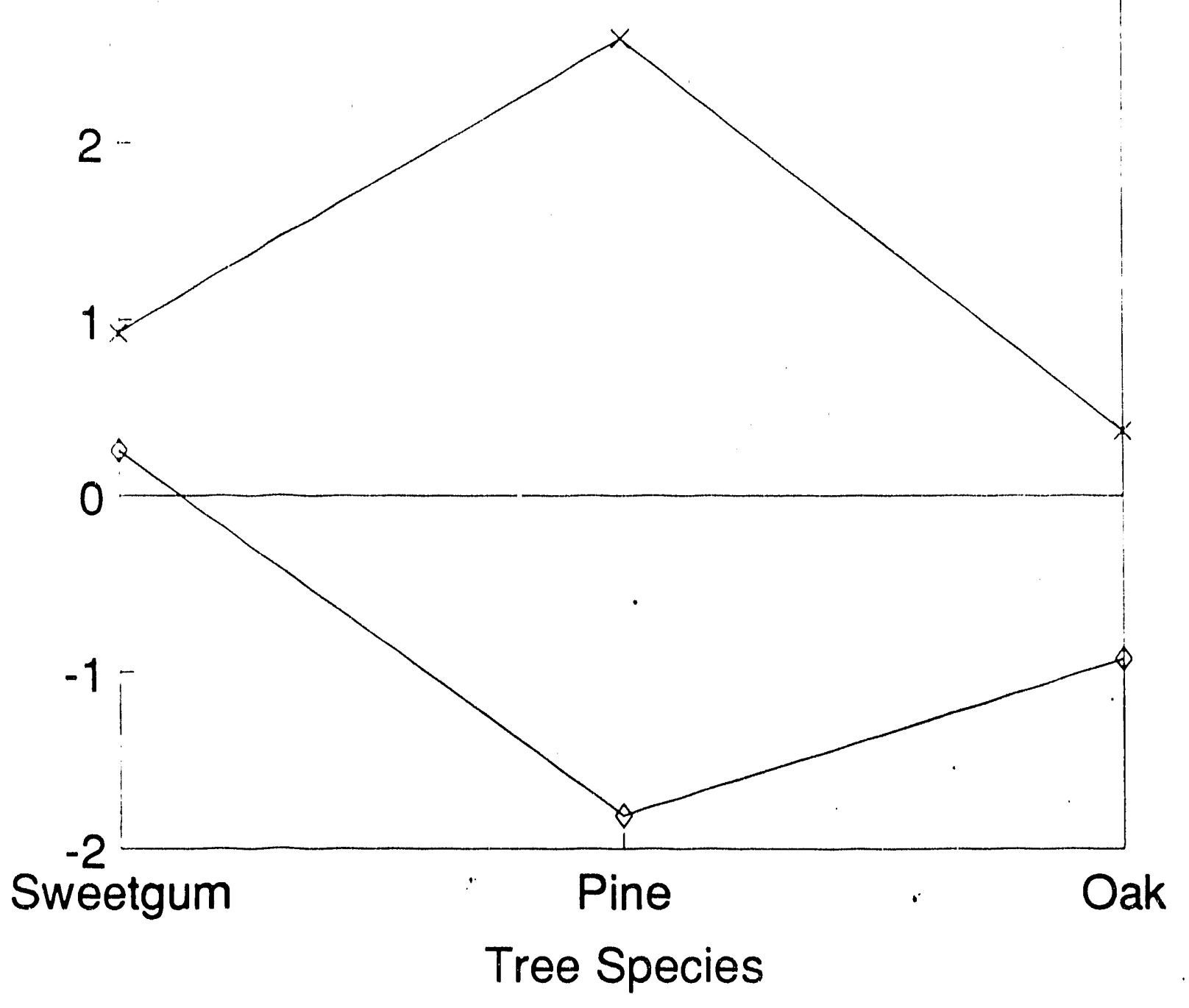

$\star$ Trench $\rightarrow$ Control 


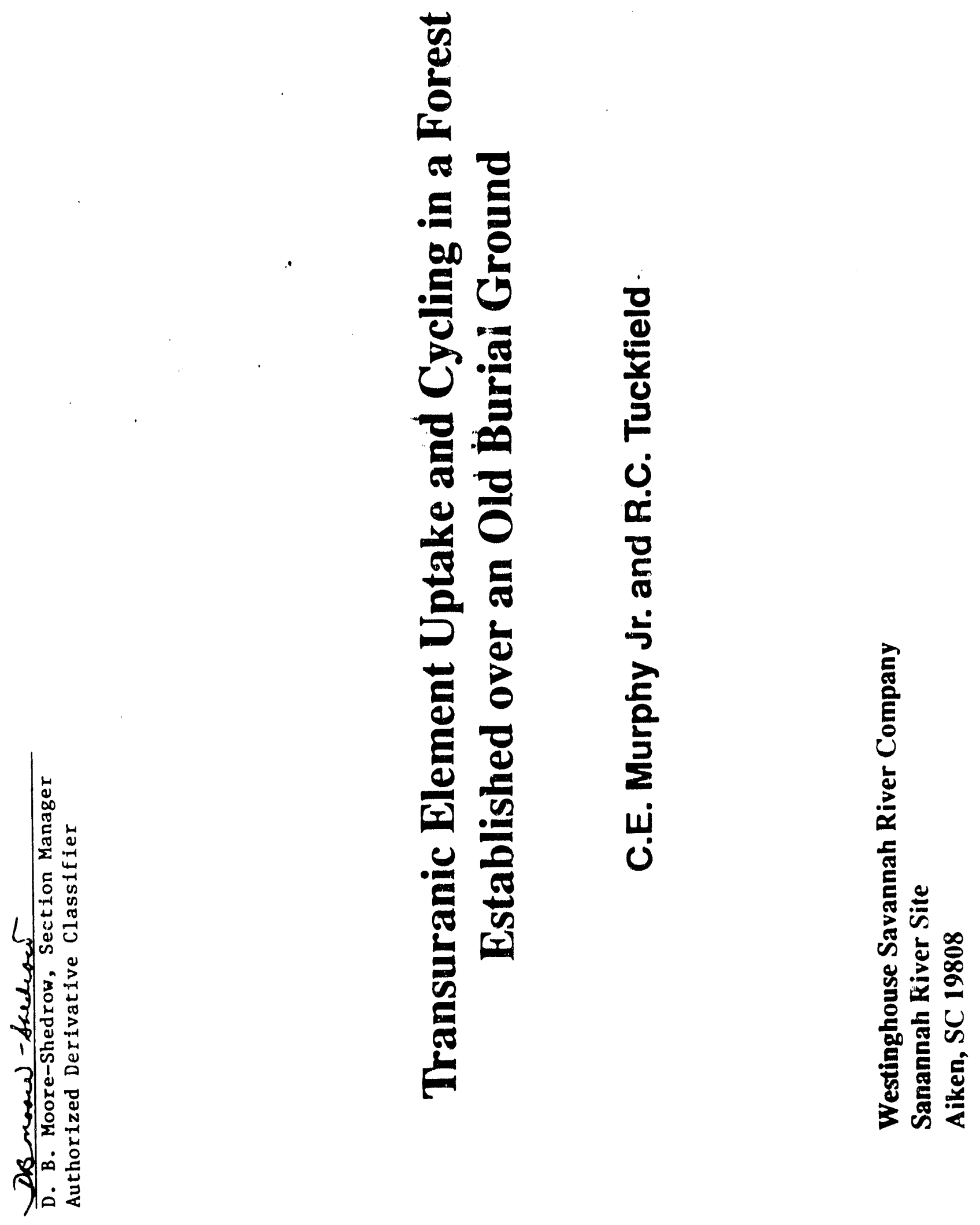




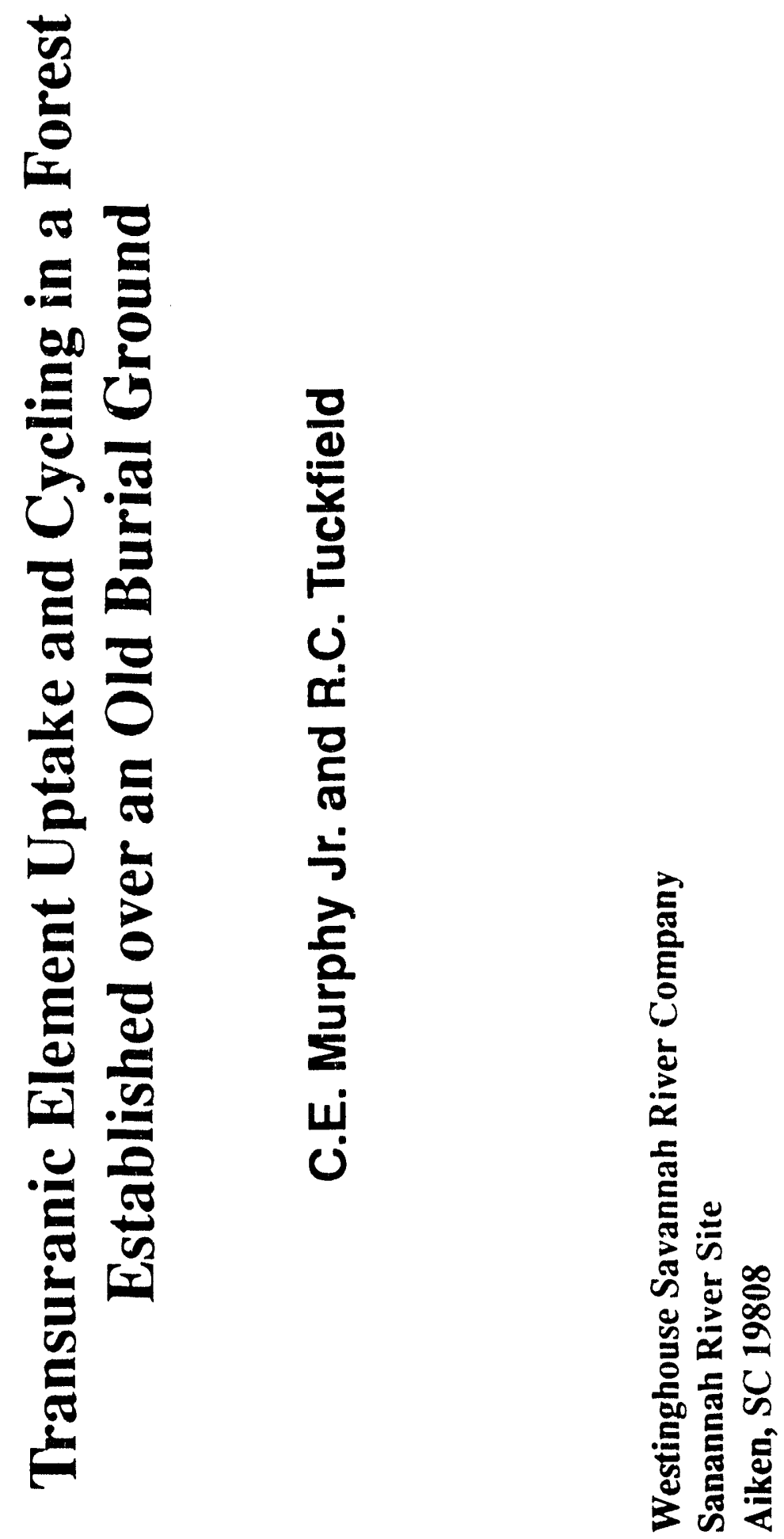



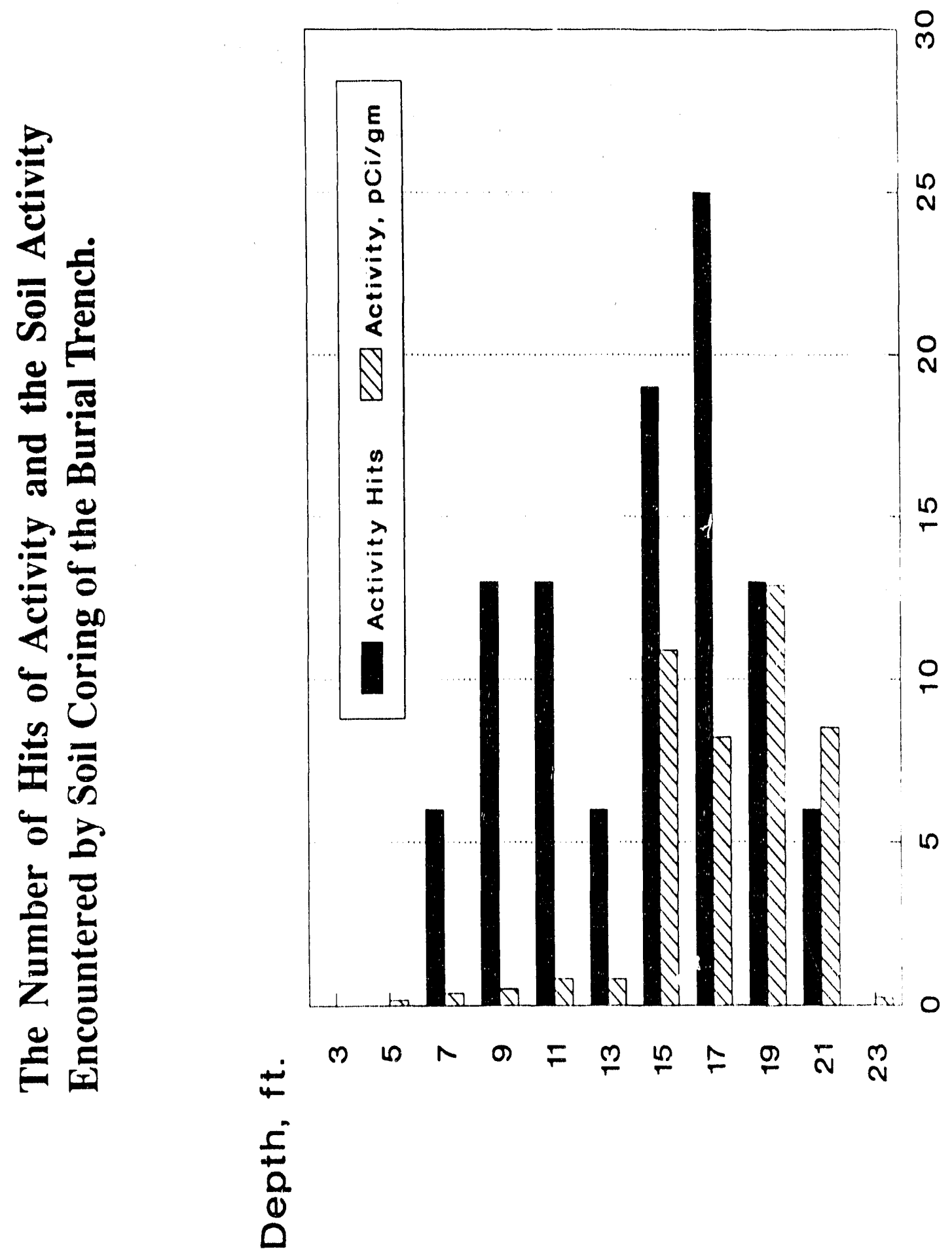

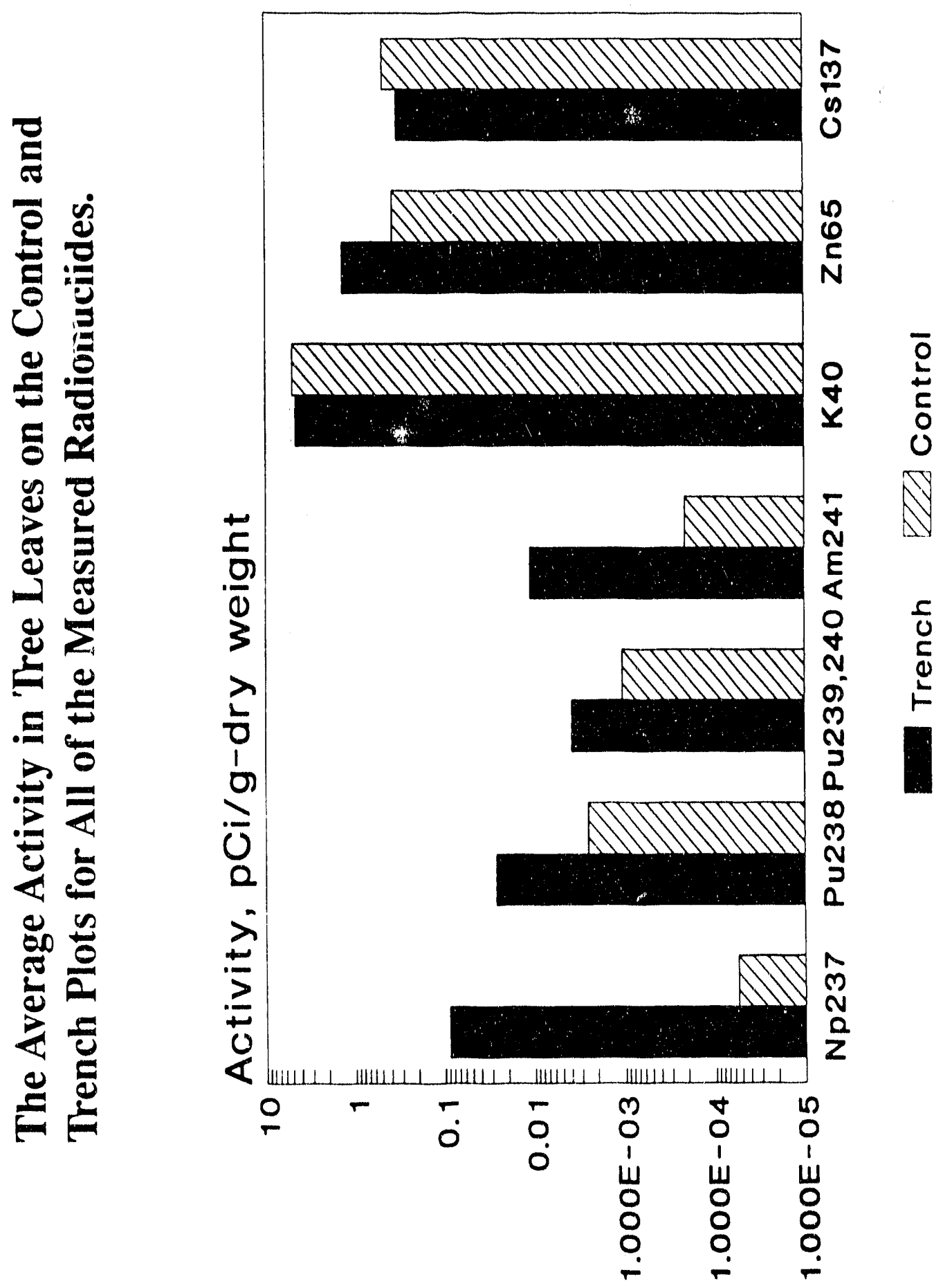


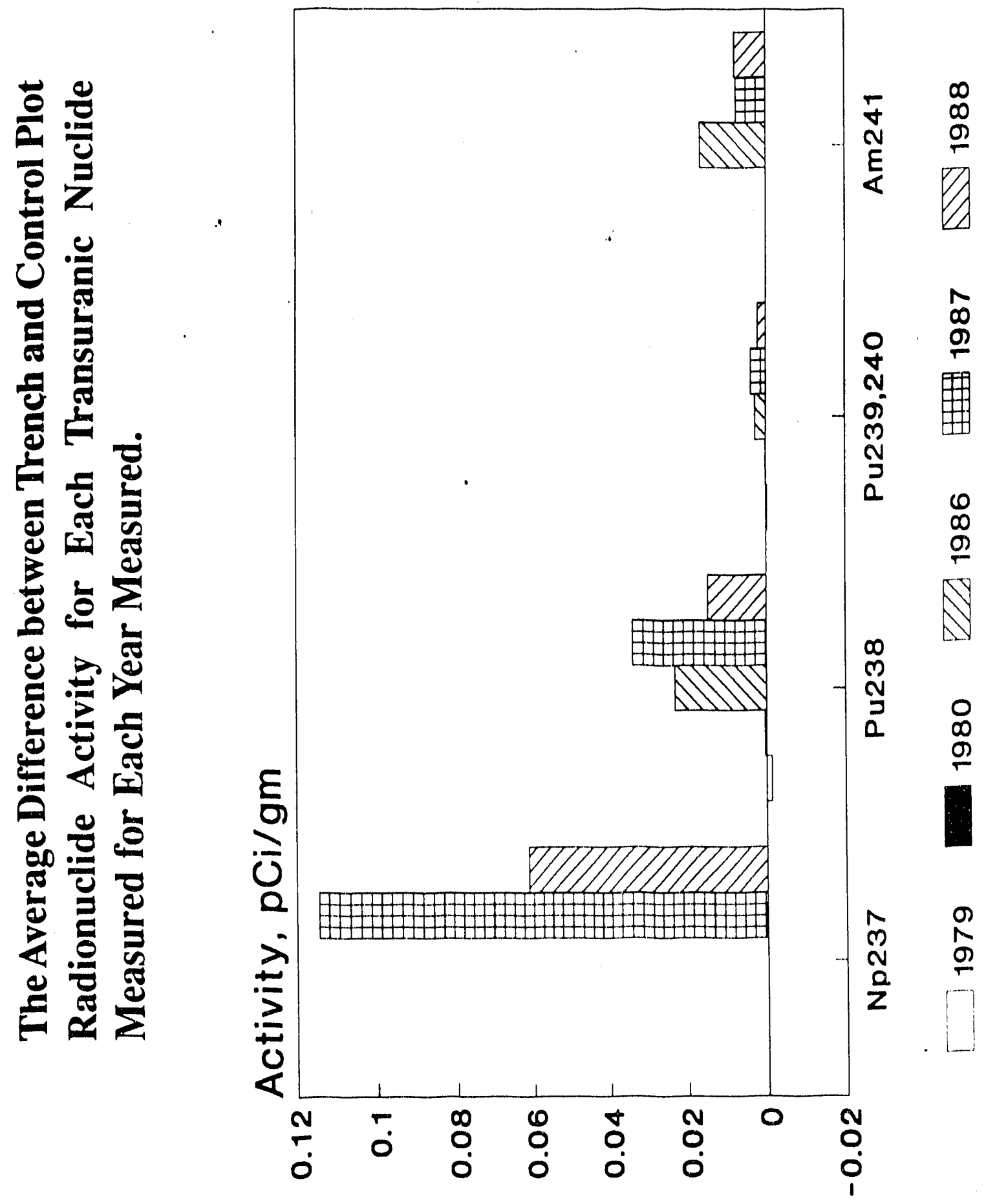



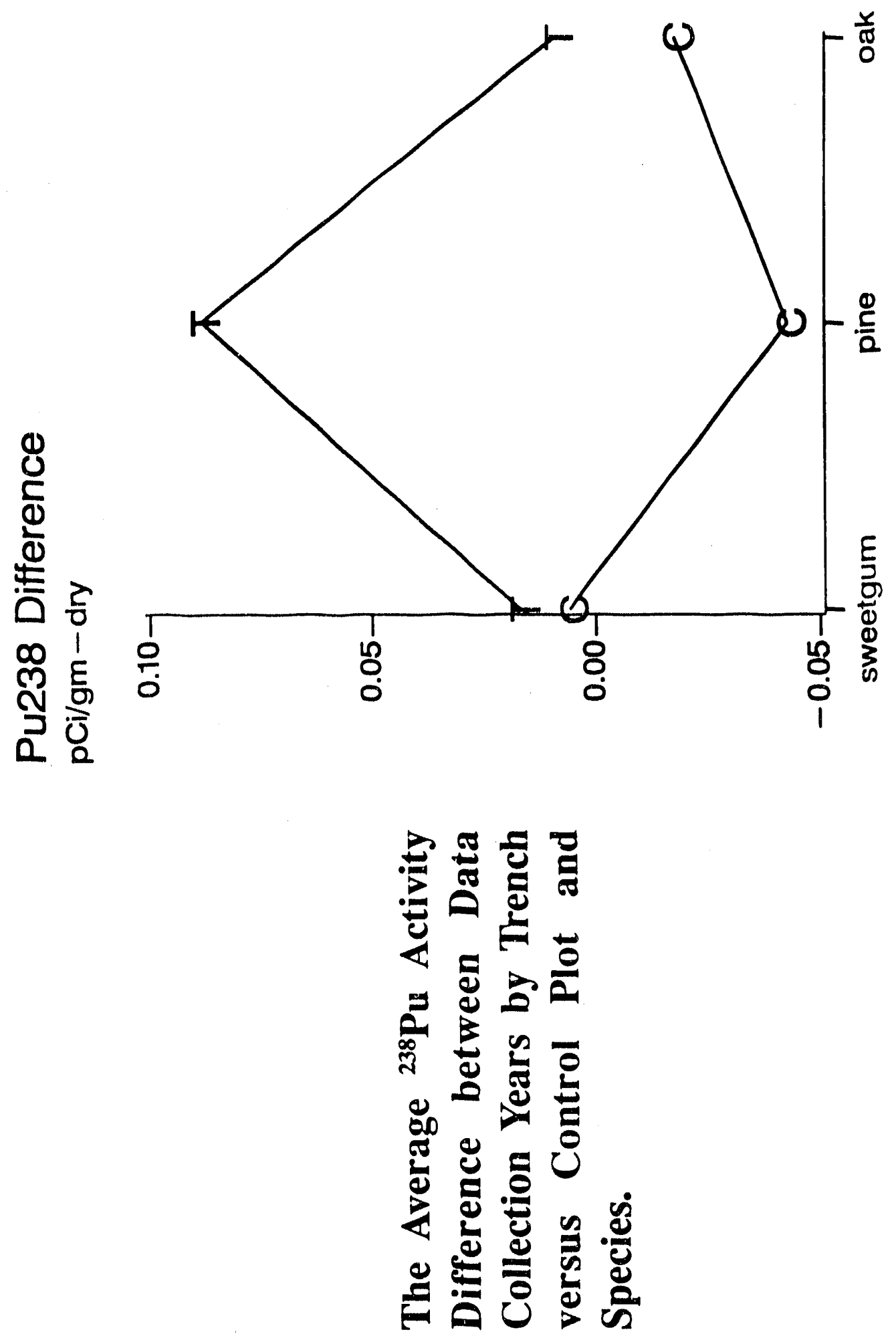

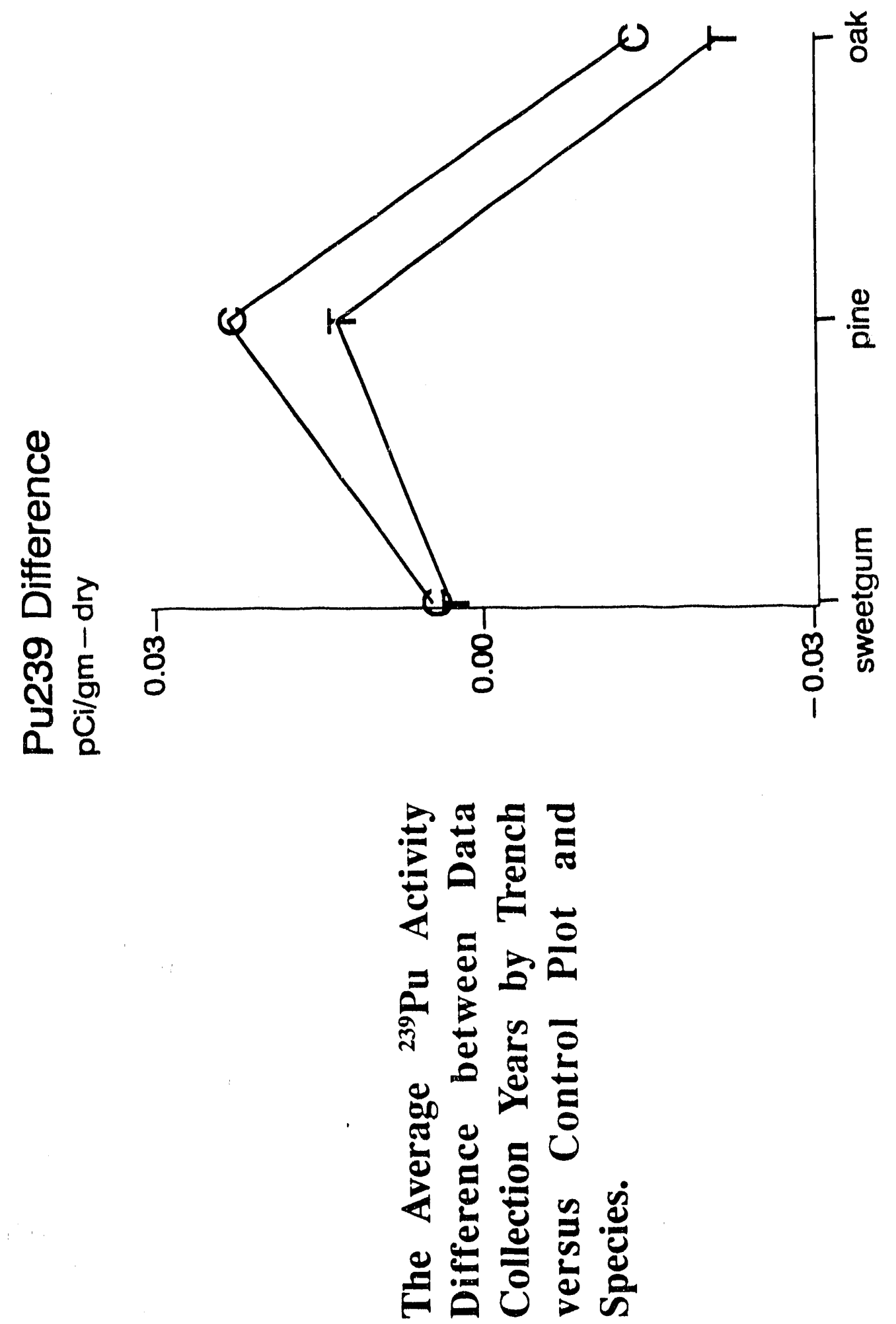


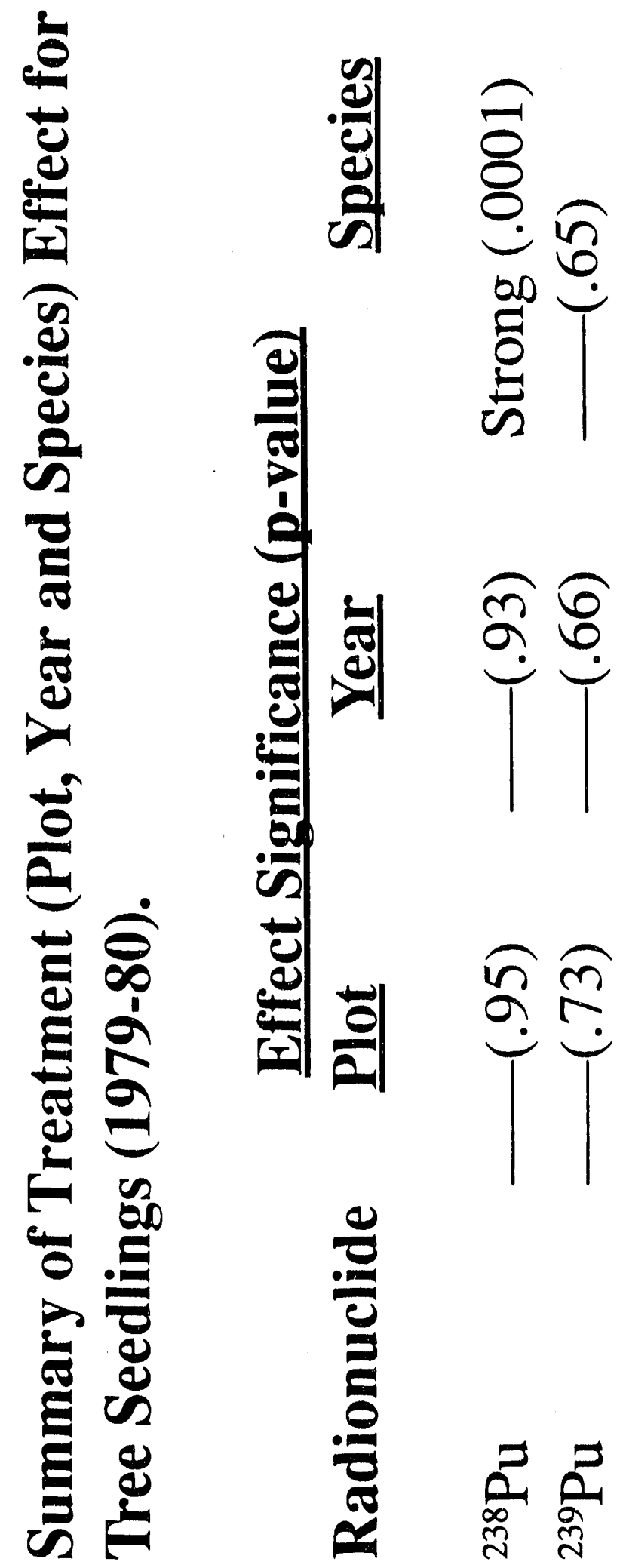




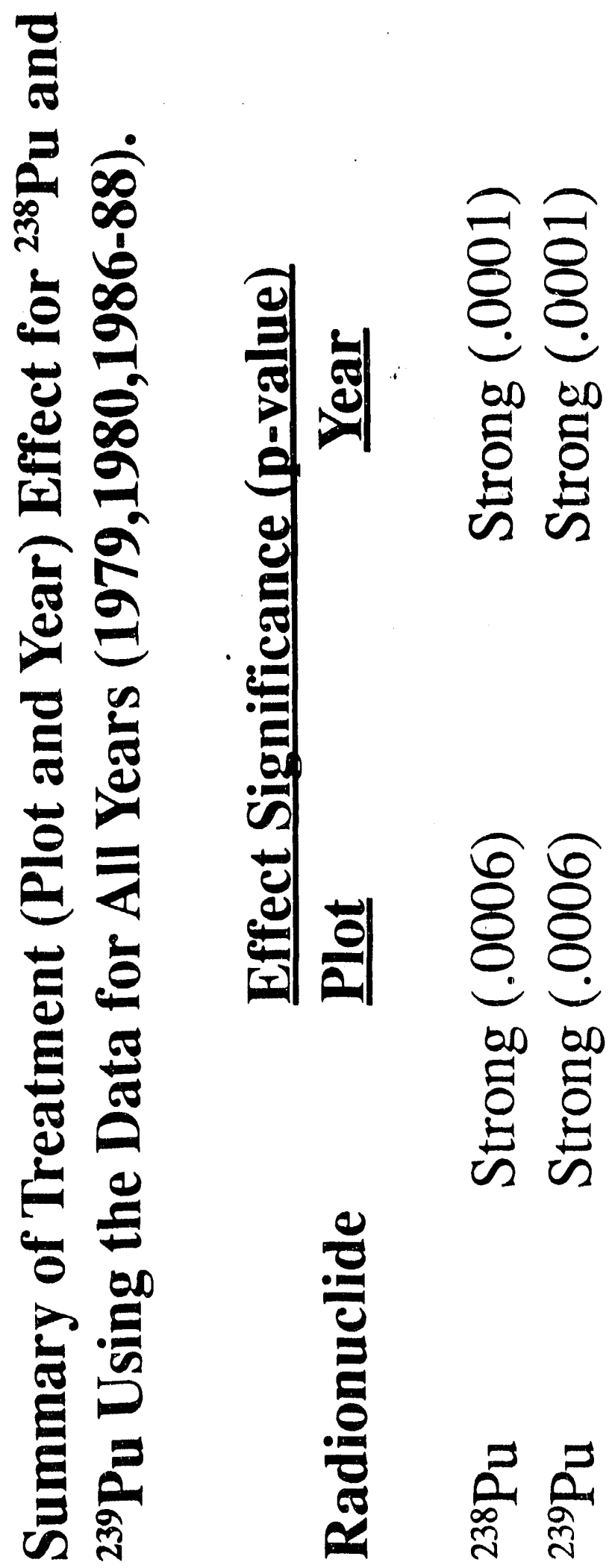




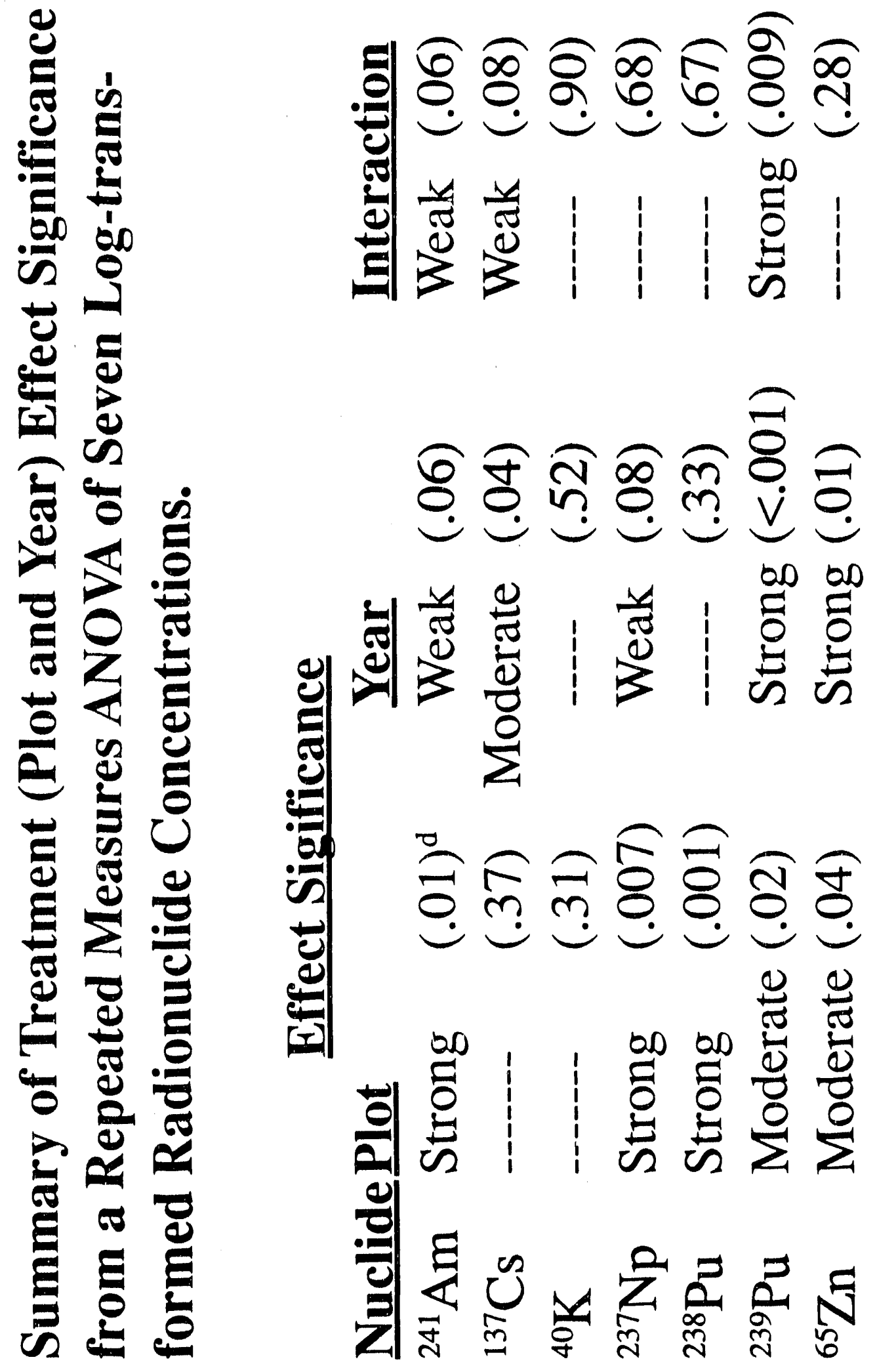



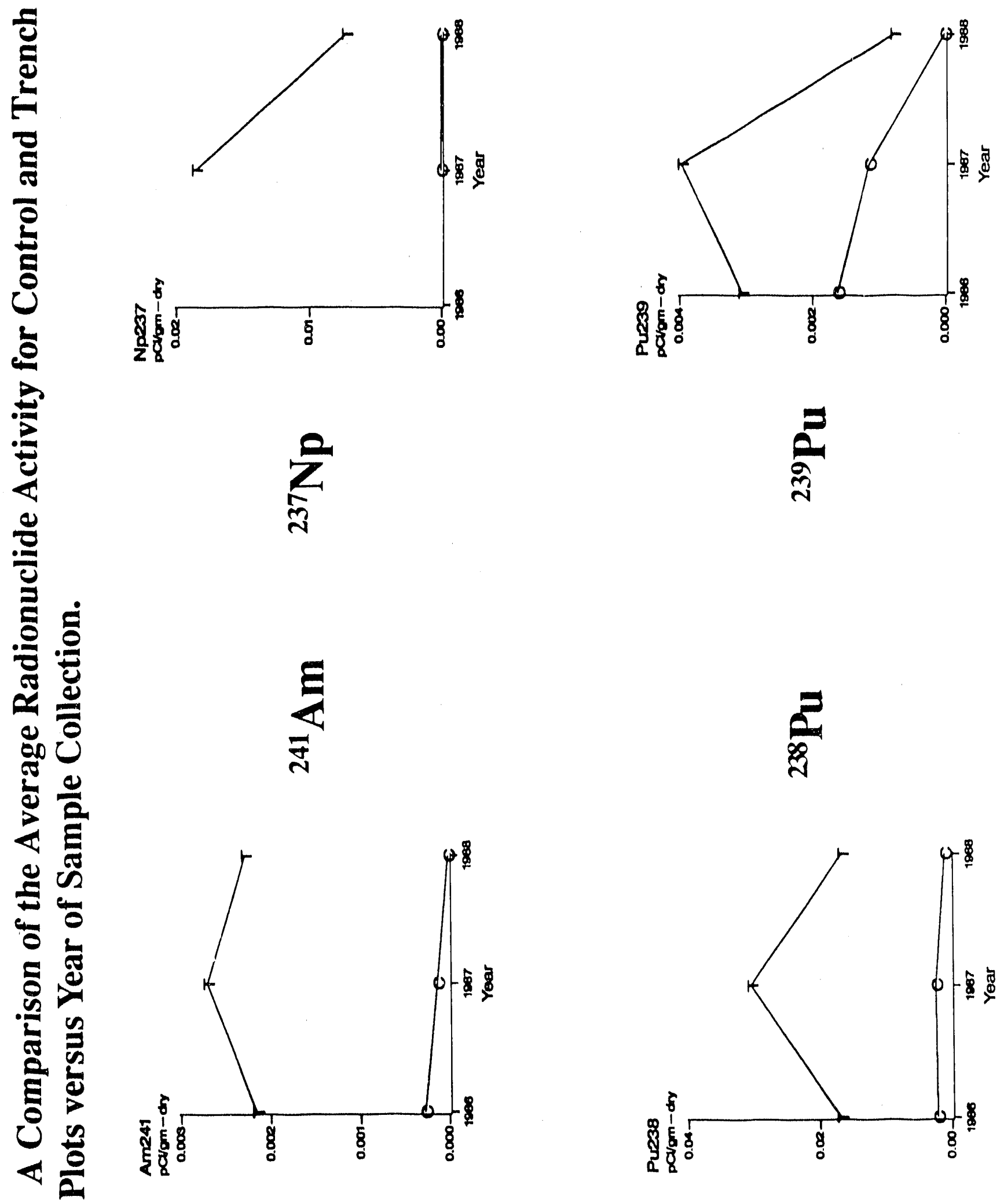

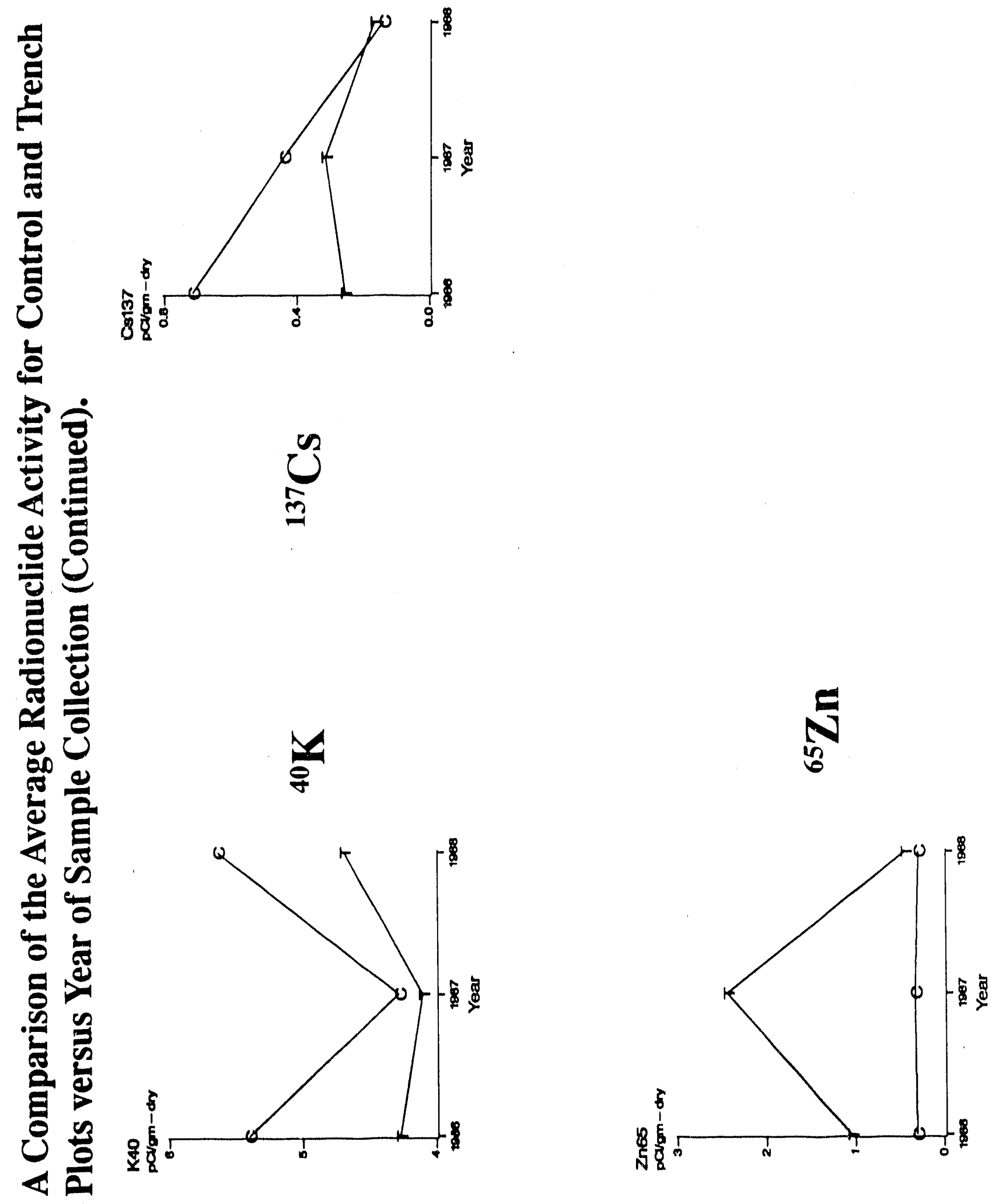


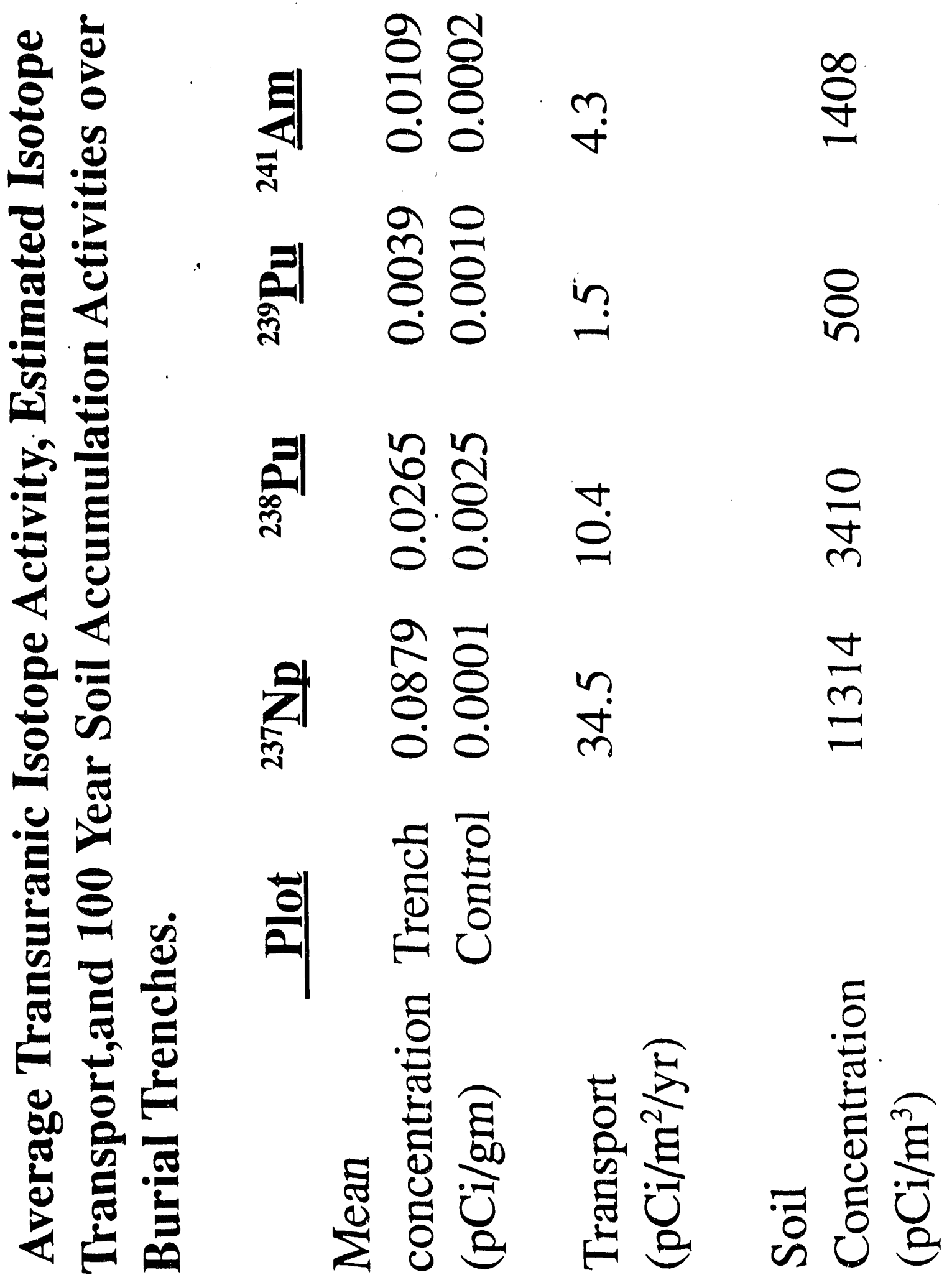




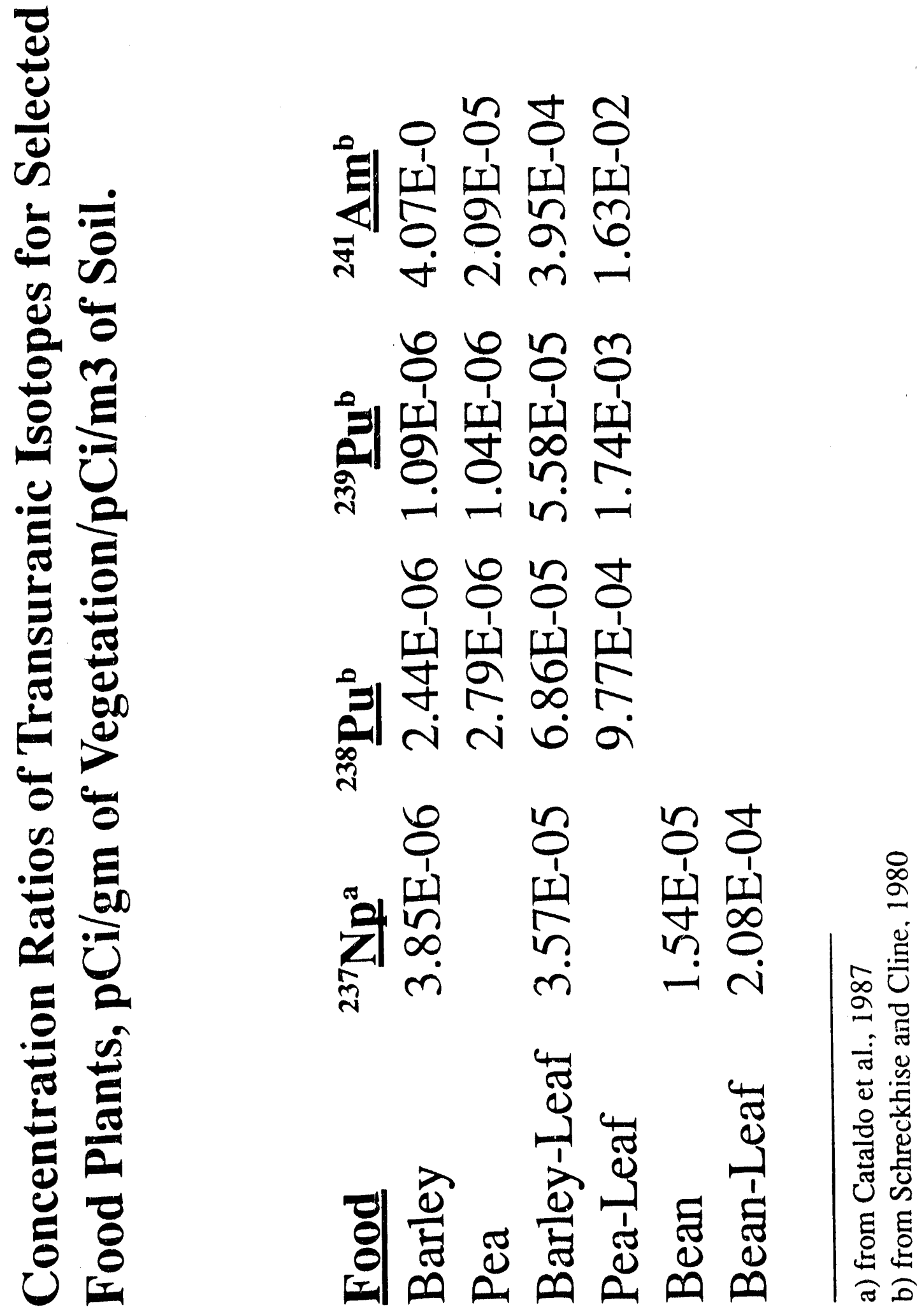




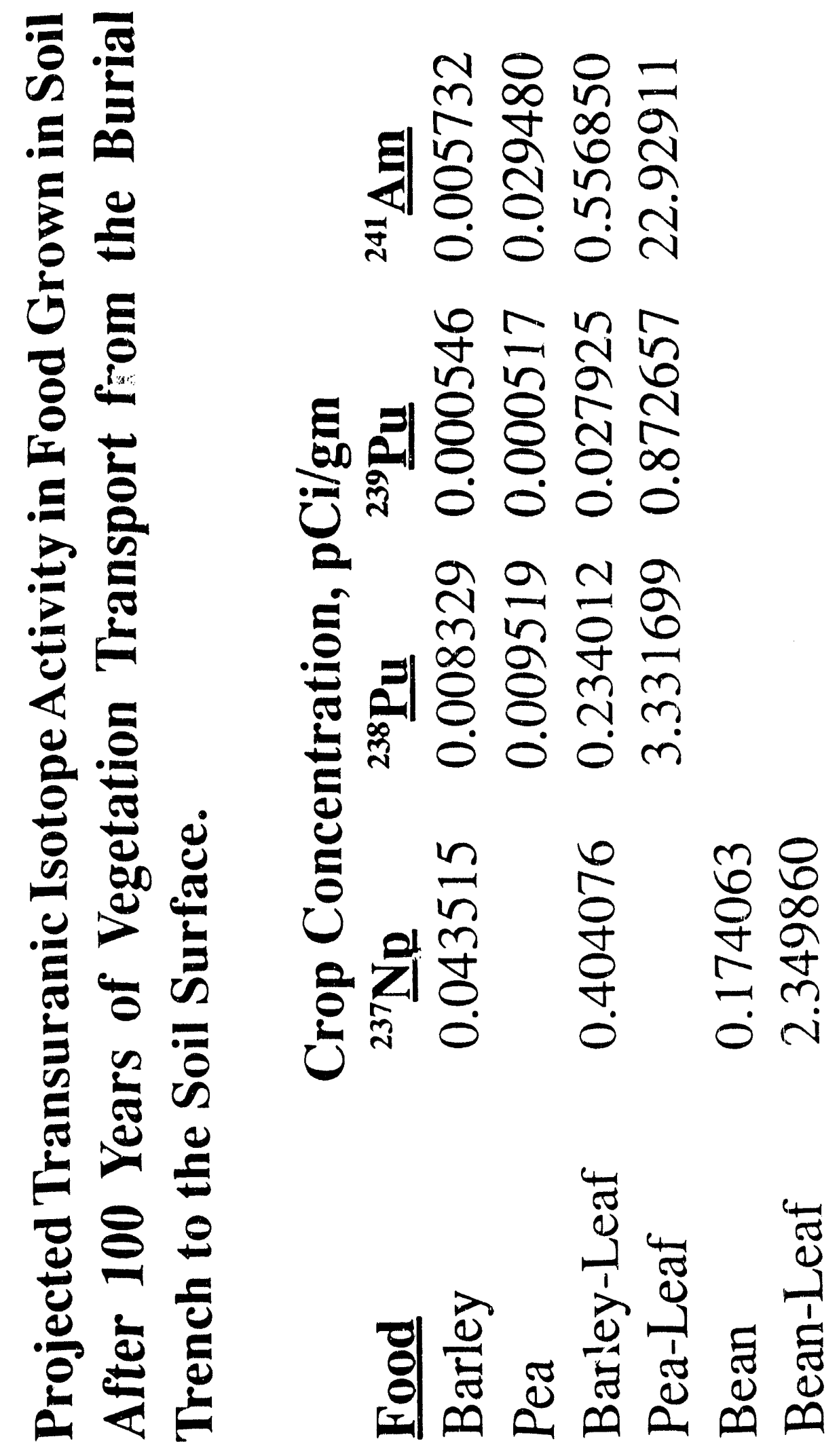




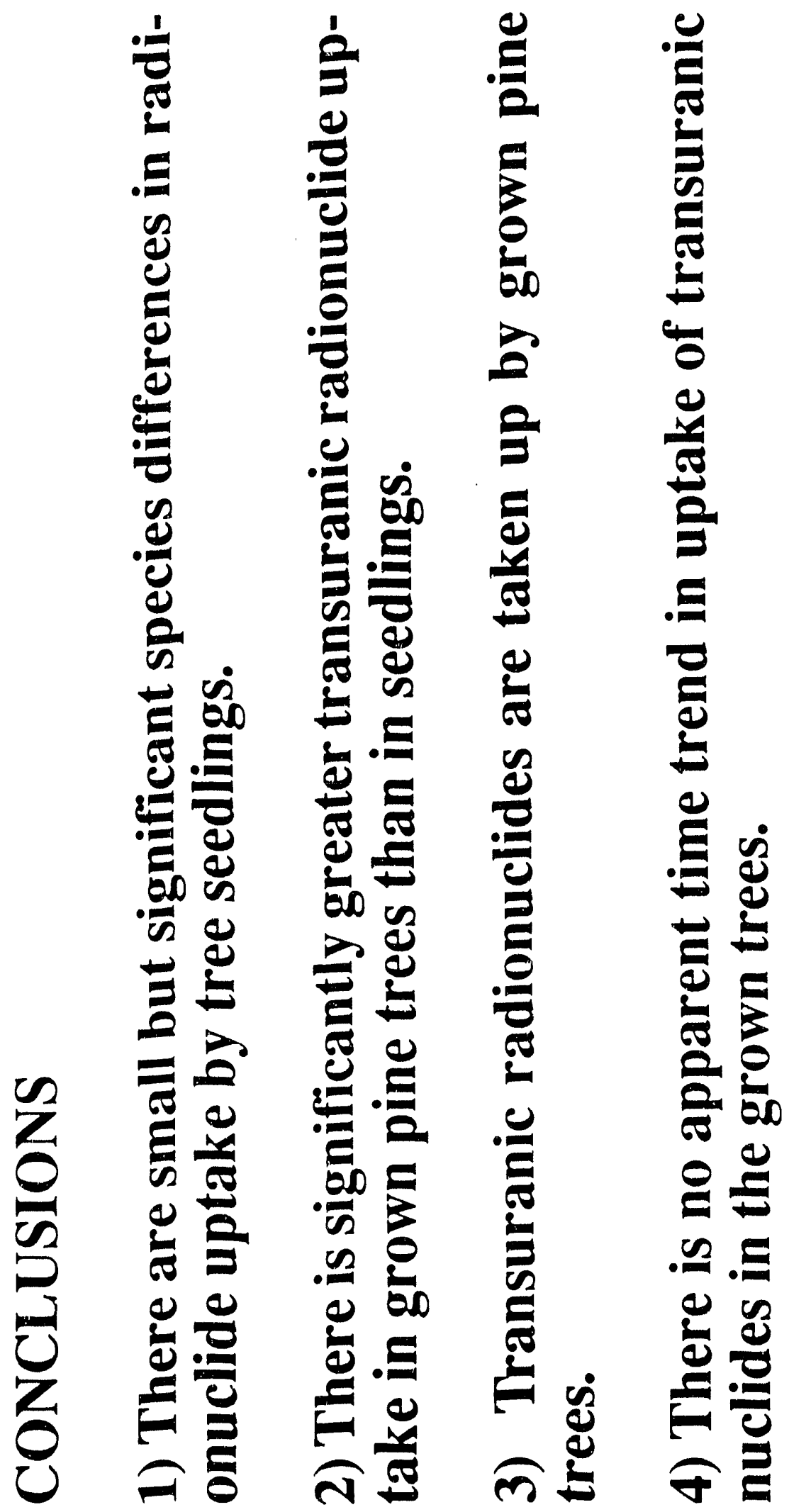


$\because$
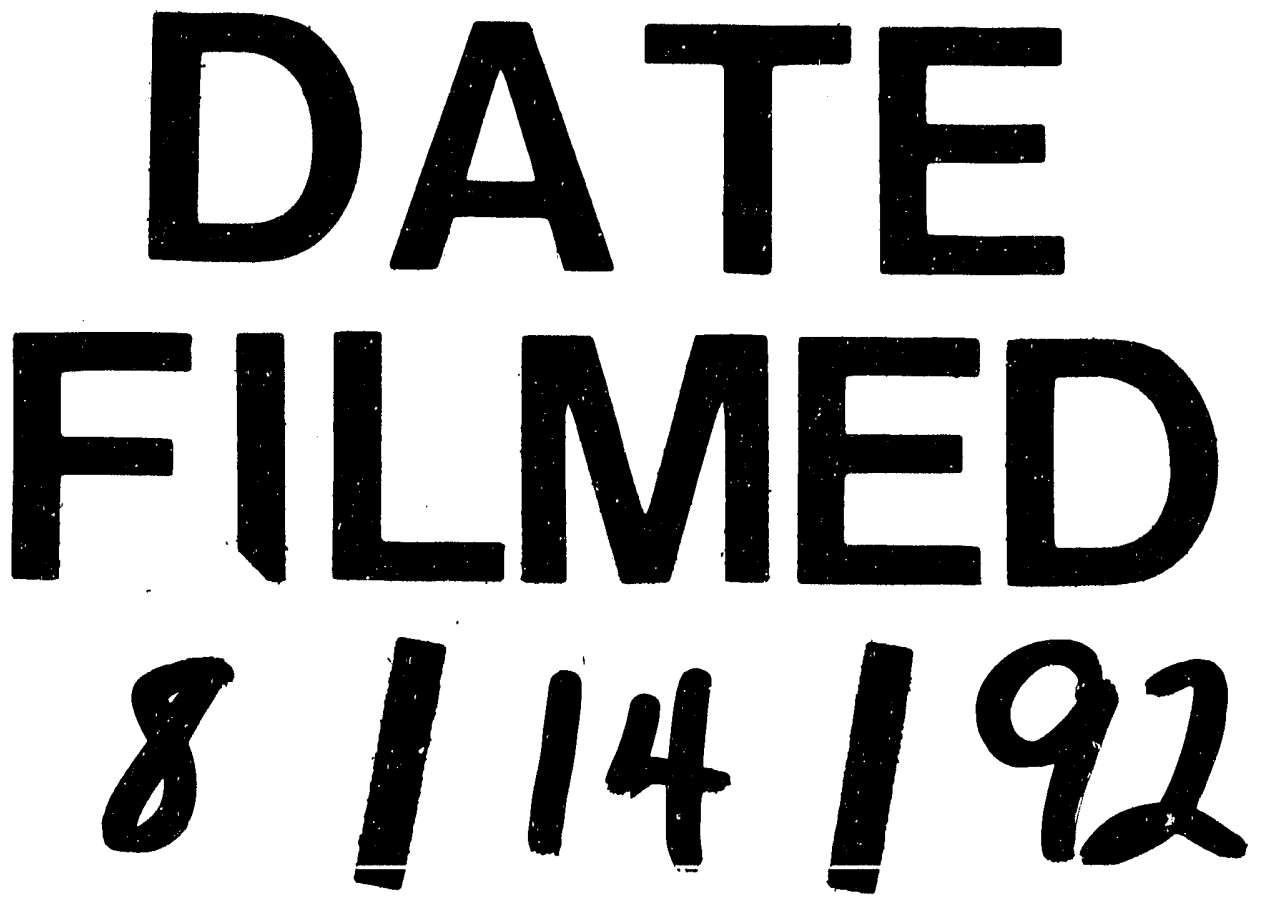
